\title{
Corporate Taxation in the United States
}

THE CORPORATION INCOME TAX has been the focus of much criticism and debate in the United States during the past decade. Many hold it responsible for the low level of business investment in the United States, and it has been criticized as a fundamentally unfair and illogical tax because it taxes corporations as independent entities, regardless of the tax brackets of individual shareholders. Much of the academic discussion in the 1970s about reform of the corporate tax centered on the integration of corporate and individual income taxes, to make the corporate tax essentially a withholding mechanism for the individual income tax. ${ }^{1}$ More recently the emphasis has shifted toward reform by repeal, and indeed President Reagan himself has called for the abolition of the corporate tax.

Any analysis of the current economic effects of the U.S. corporate tax should begin with the recognition of what has happened over the years to corporate tax revenues. Put simply, the corporate tax has been disappearing. The marked drift in composition of federal revenues away

I am grateful to James Hines and David Reishus for able research assistance, to Don Fullerton for providing unpublished data, to them and to Henry Aaron, Harvey Galper, Mervyn King, Emil Sunley, Alvin Warren, and members of the Brookings Panel for comments on early drafts, and to the Sloan Foundation for financial support through a Sloan Research Fellowship. The views expressed herein should not be attributed to any organization with which I am associated.

1. See Charles McLure, Must Corporate Income Be Taxed Twice? (Brookings Institution, 1979), and Martin Feldstein and Daniel Frisch, "Corporate Tax Integration: The Estimated Effects on Capital Accumulation and Tax Distribution of Two Integration Proposals," National Tax Journal, vol 30 (March 1977), pp. 37-52. 
from the corporate tax is illustrated in table 1, which presents the revenues from income taxes since 1953 as a percentage of federal revenues and GNP. The year 1953 is significant, for it was in 1954 that Congress passed the first of many tax acts that have successively shortened the lifetimes over which tax deductions for depreciation could be taken and accelerated the depreciation deductions within such lifetimes. The common practice through 1953 was to use straight-line depreciation for tax purposes over the allowed "useful" lives for assets. In that year the corporation income tax accounted for 28.4 percent of federal receipts and 5.4 percent of GNP. Of total income tax receipts, it accounted for about 39 percent. Throughout the late 1950s and most of the 1960 s, corporate revenues provided about one-third of total income tax revenues. A familiar rule of thumb from that era was that tax cuts should be "one-third business, two-thirds individual," perhaps reflecting this relatively stable ratio. By 1980 , the year before passage of the Economic Recovery Tax Act, corporate revenues had declined to half the level that existed in 1953, relative to GNP. The experience since then and estimates for the next five years show important additional erosion in the corporate tax as a revenue source.

This steady downward trend stands in contrast to the stability of the individual income tax, which has ranged only between 42.8 percent and 49.0 percent of revenues over the same period, and between 7.4 percent and 9.9 percent of GNP. The corporate tax will provide revenue in 1983 equal to only a small fraction of the concurrent annual federal deficit. It is in light of this low level of receipts that many have called for the abolition of the corporate tax; though if the trend in table 1 continues, little action toward this goal might seem to be required. However, changes in aggregate revenues convey only limited information about the economic impact of the corporate tax. Underlying these statistics are important distortions in the ways firms behave, with respect not only to the overall level of investment but also financial policy, asset choice, and the degree of risk-taking. The decline in corporate tax collections does not necessarily indicate a corresponding reduction in such distortions.

The purpose of this paper is to provide an economic analysis of the impact of the corporate tax in the United States as it is now and has been during the postwar years. Among the findings are the following.

1. Even accounting for inflation, the corporate tax wedge faced by 
Table 1. Sources of Federal Revenues, Fiscal Years 1953-88

\begin{tabular}{|c|c|c|c|c|}
\hline \multirow[b]{2}{*}{ Year } & \multicolumn{2}{|c|}{$\begin{array}{l}\text { Individual income } \\
\text { tax }^{\mathrm{a}}\end{array}$} & \multicolumn{2}{|c|}{ Corporate income tax } \\
\hline & $\begin{array}{l}\text { Percent of } \\
\text { federal } \\
\text { revenues }\end{array}$ & $\begin{array}{l}\text { Percent } \\
\text { of } G N P^{\mathrm{b}}\end{array}$ & $\begin{array}{c}\text { Percent of } \\
\text { federal } \\
\text { revenues }\end{array}$ & $\begin{array}{l}\text { Percent } \\
\text { of } G N P^{b}\end{array}$ \\
\hline 1953 & 45.2 & 8.6 & 28.4 & 5.4 \\
\hline 1954 & 46.0 & 8.3 & 26.3 & 4.7 \\
\hline 1955 & 44.1 & 7.4 & 28.0 & 4.5 \\
\hline 1956 & 44.0 & 8.0 & 28.2 & 5.1 \\
\hline 1957 & 45.3 & 8.3 & 25.7 & 4.7 \\
\hline 1958 & 46.5 & 8.1 & 22.9 & 4.0 \\
\hline 1959 & 44.7 & 7.8 & 25.1 & 4.4 \\
\hline 1960 & 44.8 & 8.4 & 23.5 & 4.4 \\
\hline 1961 & 45.9 & 8.3 & 21.1 & 3.8 \\
\hline 1962 & 45.4 & 8.4 & 21.8 & 4.0 \\
\hline 1963 & 45.1 & 8.3 & 21.2 & 3.9 \\
\hline 1964 & 43.9 & 8.0 & 22.2 & 4.0 \\
\hline 1965 & 42.8 & 7.4 & 22.6 & 3.9 \\
\hline 1966 & 43.3 & 7.6 & 23.2 & 4.1 \\
\hline 1967 & 44.1 & 8.1 & 20.8 & 3.8 \\
\hline 1968 & 44.7 & 8.2 & 20.7 & 3.8 \\
\hline 1969 & 47.5 & 9.6 & 19.4 & 3.9 \\
\hline 1970 & 48.3 & 9.5 & 16.9 & 3.3 \\
\hline 1971 & 45.7 & 8.2 & 16.6 & 3.0 \\
\hline 1972 & 47.1 & 8.5 & 16.0 & 2.9 \\
\hline 1973 & 44.6 & 8.1 & 17.1 & 3.1 \\
\hline 1974 & 45.2 & 8.6 & 16.0 & 3.0 \\
\hline 1975 & 45.0 & 8.2 & 14.7 & 2.7 \\
\hline 1976 & 43.6 & 8.0 & 16.7 & 3.1 \\
\hline 1977 & 45.4 & 8.7 & 16.1 & 3.1 \\
\hline 1978 & 45.0 & 8.6 & 16.2 & 3.1 \\
\hline 1979 & 46.3 & 9.2 & 15.8 & 3.1 \\
\hline 1980 & 47.6 & 9.5 & 13.3 & 2.7 \\
\hline 1981 & 47.5 & 9.9 & 11.5 & 2.4 \\
\hline 1982 & 49.0 & 9.9 & 8.1 & 1.6 \\
\hline $1983^{\mathrm{c}}$ & 47.2 & 8.9 & 6.6 & 1.3 \\
\hline $1984^{c}$ & 45.1 & 8.4 & 8.5 & 1.6 \\
\hline $1985^{\mathrm{c}}$ & 44.9 & 8.4 & 9.1 & 1.7 \\
\hline $1986^{c}$ & 45.0 & 8.3 & 9.6 & 1.8 \\
\hline $1987^{\mathrm{c}}$ & 45.2 & 8.3 & 10.1 & 1.9 \\
\hline $1988^{c}$ & 44.6 & 8.3 & 10.0 & 1.8 \\
\hline
\end{tabular}

Sources: The 1953-57 period-Economic Report of the President, January 1977, table B-72; 1958-82-Economic Report of the President, February 1983, table B-76; 1983-88-Congressional Budget Office, baseline budget projections for fiscal years $1984-88$.

a. Includes estate and gift taxes and nontax receipts, the last of which are not a significant amount.

b. For 1953-82, fiscal year revenues are divided by calendar year GNP.

c. Estimated. 
fixed investment in the aggregate has declined steadily since the early 1950s. At its minimum, in 1981, the marginal corporate tax rate was less than one-third of its 1953 level.

2. Despite this reduction in the marginal tax rate on capital taken as an aggregate, the social cost of misallocation of capital within the corporate sector that resulted from differential asset taxation, measured as a fraction of the corporate capital stock, increased over the same period, reaching an estimated peak of 3.90 percent in 1973, and equaling 3.19 percent in 1981 with the passage of the Economic Recovery Tax Act.

3. The absence of tax refunds for losses incurred by corporations results in firms with different earnings histories having different incentives to invest. Fully taxable firms quite possibly possess a stronger incentive to invest than those in the apparently favorable position of having previous losses to carry forward. This prospect has been increased by recent legislation accelerating depreciation schedules.

4. The effect of inflation on the incentive to invest is highly sensitive to the proportion of debt finance and the gap between ordinary personal and corporate tax rates. Differences in assumptions about these parameters have led to greatly varying estimates of the impact of inflation, with the direction as well as the magnitude subject to dispute.

5. Tax reform proposals should distinguish between tax revenues and marginal tax rates. Given the current pattern of asset taxation, much of the present value of revenues that will come from the corporate tax can be attributed to assets already in place. Hence abolition of the corporate tax would accomplish a small reduction in the average marginal tax rate at the expense of a large, essentially lump-sum transfer to the owners of existing capital. This transfer would have been approximately \$427 billion in 1981 .

The paper begins with a review of the corporate tax and its provisions and the major changes that generated the pattern of revenues presented in table 1.

\section{The Corporate Tax: 1953-81}

The corporate tax is essentially a flat rate tax; it is currently 46 percent. ${ }^{2}$ There has been little movement in the statutory corporate tax

2. Under current law the first $\$ 100,000$ of a corporation's income is taxed at rates 
rate during the past three decades. As shown in the second column of table 2, the rate was reduced from 52 percent to 48 percent by the 1964 tax cut, raised temporarily by the 10 percent Vietnam War surcharge, and lowered again by the tax act of 1978 to its current level. Most of the "action" in the corporate tax has come from changes in the tax base.

The tax base for a nonfinancial corporation investing in fixed assets is derived by subtracting from gross sales the costs of inputs (including wages and materials), capital costs (through depreciation allowances), and interest payments. This base is effectively reduced when any of these components increases or when tax credits are allowed against calculated tax liabilities. Through various legislation, there have been increases in levels of depreciation allowances and credits at any given level of income. Increases in the inflation rate have brought declines in the real value of depreciation allowances and measured materials costs and increases in interest payments.

Either through shortened tax lifetimes or increased speed of write-off over such lifetimes, depreciation allowances were accelerated in 1954, 1962,1971 , and 1981. All these actions had the effect of raising the present value of depreciation allowances received per dollar invested. The investment tax credit was introduced in 1962, briefly suspended in 1966, removed in 1969, reinstated in 1971, increased in 1975 , and altered by both the 1981 and 1982 tax acts. ${ }^{3}$ Thus, there has been a general legislative movement toward reduced corporate taxation, since most nonresidential fixed investment is undertaken by corporations.

As has been emphasized by many authors, inflation affects taxable corporate profits in three important ways. ${ }^{4}$ To the extent that the first-

below the maximum rate of 46 percent. The only important class of corporation taxpayers without most income in the top bracket are companies with negative taxable income that face a tax rate of zero. This is discussed further below.

3. For a historical review of these changes, see Alan J. Auerbach, "The New Economics of Accelerated Depreciation," Boston College Law Review, vol. 23 (September 1982), pp. 1327-55.

4. See, for example, John B. Shoven and Jeremy I. Bulow, "Inflation Accounting and Nonfinancial Corporate Profits: Physical Assets," BPEA, 3:1975, pp. 557-98; T. Nicholaus Tideman and Donald P. Tucker, "The Tax Treatment of Business Profits Under Inflationary Conditions," in Henry J. Aaron, ed., Inflation and the Income Tax (Brookings Institution, 1976), pp. 33-77; Martin S. Feldstein and Lawrence Summers, "Inflation and the Taxation of Capital Income in the Corporate Sector," National Tax Journal, vol. 32 (December 1979), pp. 445-70; and Alan J. Auerbach, "Inflation and the Tax Treatment of Firm Behavior," American Economic Review, vol. 71 (May 1981, Papers and Proceedings, 1980), pp. 419-23. 
Table 2. Average Corporate Tax Rates, 1953-82

Percent

\begin{tabular}{|c|c|c|c|}
\hline Year & $\begin{array}{c}\text { Average } \\
\text { corporate } \\
\text { rate }^{\text {a }}\end{array}$ & $\begin{array}{c}\text { Statutory } \\
\text { corporate } \\
\text { rate }\end{array}$ & Difference \\
\hline 1953 & 55.9 & 52.0 & -3.9 \\
\hline 1954 & 50.0 & 52.0 & 2.0 \\
\hline 1955 & 48.4 & 52.0 & 3.6 \\
\hline 1956 & 50.3 & 52.0 & 1.7 \\
\hline 1957 & 49.4 & 52.0 & 2.6 \\
\hline 1958 & 49.4 & 52.0 & 2.6 \\
\hline 1959 & 47.6 & 52.0 & 4.4 \\
\hline 1960 & 47.7 & 52.0 & 4.3 \\
\hline 1961 & 46.9 & 52.0 & 5.1 \\
\hline 1962 & 42.4 & 52.0 & 9.6 \\
\hline 1963 & 42.2 & 52.0 & 9.8 \\
\hline 1964 & 40.5 & 50.0 & 9.5 \\
\hline 1965 & 38.6 & 48.0 & 9.4 \\
\hline 1966 & 39.6 & 48.0 & 8.4 \\
\hline 1967 & 39.4 & 48.0 & 8.6 \\
\hline 1968 & 44.0 & 52.8 & 8.8 \\
\hline 1969 & 46.4 & 52.8 & 6.4 \\
\hline 1970 & 47.9 & 49.2 & 1.3 \\
\hline 1971 & 45.1 & 48.0 & 2.9 \\
\hline 1972 & 43.1 & 48.0 & 4.9 \\
\hline 1973 & 45.2 & 48.0 & 2.8 \\
\hline 1974 & 54.4 & 48.0 & -6.4 \\
\hline 1975 & 45.8 & 48.0 & 2.2 \\
\hline 1976 & 46.2 & 48.0 & 1.8 \\
\hline 1977 & 43.5 & 48.0 & 4.5 \\
\hline 1978 & 43.2 & 48.0 & 4.8 \\
\hline 1979 & 45.0 & 46.0 & 1.0 \\
\hline 1980 & 46.6 & 46.0 & -0.6 \\
\hline 1981 & 42.6 & 46.0 & 3.4 \\
\hline 1982 & 36.5 & 46.0 & 9.5 \\
\hline
\end{tabular}

Sources: Average rates are from Economic Report of the President, February 1983, table B-82; statutory rates are from appendix $\mathrm{A}$.

a. Corporate tax liability as a percentage of corporate profits with inventory valuation and capital consumption adjustments.

in, first-out (FIFO) inventory method is used, rising prices lead to an understatement of materials costs, and purely nominal "inventory profits" are taxed. Because depreciation allowances are based on historical asset cost, their real value declines with increases in the price level. Finally, nominal interest payments include an inflation premium 
that is essentially a return of principal to bondholders. Yet these payments are fully deductible to the corporate borrower. This last effect works against the first two, lowering corporate tax liabilities, though there may be offsetting effects at the individual level, both with respect to the taxation of interest received and nominal capital gains on stock. ${ }^{5}$

The combined impact of changes in the tax law and, through modifications in the inflation rate, implicit changes in the treatment of inventories and depreciation can be seen in table 2, which compares average corporate tax rates (corporate taxes as a percentage of corporate profits corrected with the capital consumption and inventory valuation adjustments) over the past thirty years with the statutory tax rates over the same period. (Since nominal interest payments are deducted from this profits measure, as well as the tax base, increases in interest payments lower both numerator and denominator of the average tax rate calculation.) The primary differences in the two tax rates for a given year come from investment tax credits and discrepancies between estimates of actual depreciation and materials costs and those actually deducted on tax returns. When the statutory rate exceeds the average rate, the effect of investment tax credits and accelerated depreciation allowances outweighs the erosion of such allowances and taxation of inventory gains caused by inflation.

The effects of both legislated and inflation-induced tax changes can be clearly seen in the table. In 1953 the average corporate tax rate exceeded the statutory rate. Since the inflation rate in that year was below 1 percent, this must be due to the use of straight-line depreciation that was less generous than the economic depreciation estimated for the national income accounts. With the 1954 legislation, average tax rates fell below 52 percent. The gap widened further with the introduction of the investment tax credit in 1962. As inflation increased in the late 1960s, the gap narrowed again, increasing with the additional tax incentives of 1971 and 1975 and decreasing in years of serious inflation such as 1974. Except for the initial drop in the early 1950s and the recent decline caused by the 1981 and 1982 legislation, there is no obvious trend in average corporate tax rates during the period.

There are two factors that reconcile these results with the declining

5. Estimates of the inflation-induced tax payments at the individual level are presented in Feldstein and Summers, "Inflation and the Taxation of Capital Income in the Corporate Sector." 
revenues shown in table 1 . First, the increase in nominal interest rates during the 1970 s, combined with a relatively stable aggregate corporate debt-equity ratio, decreased measured corporate profits as a fraction of GNP. ${ }^{6}$ Second, even with interest payments added back in, there is evidence that the total return to corporate capital declined during the 1970 s. ${ }^{7}$ Neither of these factors necessarily indicates a lessening of the impact of the corporate tax on behavior, as discussed below.

\section{The Recent Tax Acts}

The Economic Recovery Tax Act of 1981 substantially reduced the corporate tax burden by replacing the system of numerous asset depreciation classes with three "capital recovery" classes. Light equipment can be written off over three years, other equipment over five years, and business structures over fifteen years. The associated reduction in taxes was mitigated by the passage of the Tax Equity and Fiscal Responsibility Act of 1982, which repealed accelerations in the write-off pattern that were to have occurred in 1985 and 1986 and instituted a basis adjustment of 50 percent for the investment tax credit. That is, investors receiving the 10 percent investment tax credit now receive depreciation deductions on a base of 95 cents per dollar of capital purchased ${ }^{8}$ Another important change brought about by the 1982 act was the reduction and eventual repeal of the "safe-harbor leasing" mechanism introduced by the 1981 act to facilitate the transfer of tax deductions and credits from one company (typically not with positive taxable income) to another. This last change is discussed in greater detail below.

The estimated net impact of the 1981 and 1982 acts on corporate tax revenues is evident in tables 1 and 2. As a percent of GNP, corporate

6. For more detail on this debt-equity ratio see Roger H. Gordon and Burton G. Malkiel, "Corporation Finance," in Henry J. Aaron and Joseph A. Pechman, eds., How Taxes Affect Economic Behavior (Brookings Institution, 1981), pp. 131-96.

7. This point is the subject of some dispute. Although Martin Feldstein and Lawrence Summers, "Is the Rate of Profit Falling?"' BPEA, 1:1977, pp. 211-28, argue that observed declines were primarily cyclical, recent evidence presented in Barry Bosworth, "Capital Formation and Economic Policy," BPEA, 2:1982, pp. 273-317, makes a compelling case for a secular decline in the rate of return to capital.

8. These changes are described in more detail in Auerbach, "The New Economics of Accelerated Depreciation." 
tax collections fell by approximately 40 percent from 1980 to 1982, and the average corporate tax rate fell to a new low in 1982.

\section{Identifying the Appropriate Marginal Tax Rate}

Many authors have used average tax rates such as those in table 1 or related measures incorporating interest payments and personal taxes to determine the impact of the corporate tax on the incentive to invest. ${ }^{9}$ For several important reasons, however, such measures may fail to capture changes in the marginal tax rate on income from new capital investment.

\section{RETURNS TO NONCAPITAL FACTORS}

Corporations receive income in excess of a competitive return to capital. The sources of such income may include but are not limited to the entrepreneurial ability of management and the exercise of market power. Because such income does not come from depreciable capital that benefits from accelerated depreciation allowances, nor does it qualify for an investment tax credit, it faces an effective tax rate equal to 46 percent. Such taxation is not directly relevant to the incentive to invest in fixed capital, but is incorporated in measured average tax rates.

\section{RETURNS TO OLD CAPITAL}

Even when the tax law is not changed over time (by legislation or inflation), assets of different vintages face different tax rates in a given year on the income they generate. This is easily illustrated by considering equipment purchased under the 1981 tax law. After five years, the equipment receives no depreciation allowances-its gross rents are fully taxed. In the year of its purchase, the equipment received not only a substantial depreciation allowance (15 percent) but also a 10 percent investment tax credit. ${ }^{10}$ Because of the acceleration of depreciation

9. See, for example, Feldstein and Summers, "Inflation and the Taxation of Capital Income in the Corporate Sector.',

10. The 15 percent allowance corresponds to half of the first year of depreciation permitted a five-year asset under the 150 percent declining balance formula. The so-called half-year convention built into the 1981 formulas gives assets a half year of allowances during the first year, irrespective of purchase date. 
allowances relative to actual depreciation, taxable income is lower in the early years of the asset's life and higher in the later years than a true measure of income. Assets face higher taxes on the income they generate in later years relative to earlier years. Since a capital investment generates income over many years, these tax rates must be combined in some useful way to derive the overall impact of taxation on that investment. Simple averaging of tax rates over vintages of assets in a given year does not give the correct answer: as a result of changes in the tax code, assets of older vintages are currently being depreciated under tax rules that do not apply to new investment; there is no reason for the relative quantities of capital by vintage to correspond to the relative incomes, which differ at different ages for a given vintage; and simple averaging ignores discounting. I return to this subject below to show how the appropriate calculation can be done.

\section{ANTICIPATED CHANGES IN THE TAX CODE}

It does not require strong assumptions about rational expectations to conclude that investors may anticipate future changes in the tax law. Sometimes these changes are embodied in legislation already in place. Such was the case in 1981, when increases in the generosity of depreciation schedules were to take place in 1985 and $1986 .{ }^{11}$ Since existing assets generally cannot be converted to the new schedules, anticipated tax incentives can represent an implicit tax on current investment. This has long been recognized but is not accounted for in the computation of average annual tax rates.

\section{ASYMMETRIES IN THE TREATMENT OF GAINS AND LOSSES}

The tax code imposes essentially two corporate tax rates: 46 percent on positive taxable income and zero on negative taxable income. If a firm incurs a tax loss, it has two alternatives. If sufficient taxes were paid during the previous three tax years, the current tax loss may be "carried back" and used to offset previous taxable income, with a resulting tax refund equal to 46 percent of the current loss. To this extent, current

11. Because such changes were repealed in 1982 , fully rational investors might have anticipated this in 1981 and expected no change to occur in 1985 and 1986. 
losses do receive the same treatment as gains. If, however, the current loss exceeds the previous three years' taxable income, the excess must be "carried forward," with the hope that future income will be sufficient to absorb it. Since losses carried forward do not accrue interest, they decline in present value at the nominal interest rate. The current limitation to carrying forward is fifteen years, increased from seven years by the 1981 act.

This feature of the tax code affects new investment in two ways. First, firms currently carrying losses forward face a different pattern of expected deductions, credits, and taxable income than do firms currently taxable. Second, even taxable firms face the possibility of being nontaxable, and therefore losing the value of tax deductions, at some future date.

The motivation behind this feature of the law may in part be protection against fraudulent losses produced by fictitious companies and "hobby" losses in which consumption expenditures are characterized by the taxpayer as business expenses. That the absence of tax deductibility was perceived as a problem for legitimate businesses became evident when the 1981 act included a provision making it easier for firms to transfer tax benefits to other firms through the guise of leasing. The complicated impact of the asymmetry of the taxes on losses and gains cannot be captured by aggregate average tax rates. Different firms could face enormously different marginal tax rates on the same new investment because of differences in their current or anticipated status with regard to taxable income.

RISK

Average tax rates for the corporate sector are calculated by comparing taxes to earnings, but these may have different risk characteristics. Corporate earnings are extremely volatile, while depreciation allowances are known with a fair amount of certainty, at least in nominal terms. The extent to which measured ex post tax rates accurately reflect the real burden imposed by the tax system ex ante has been the subject of much recent discussion.

In the remaining sections of this paper I explore the impact of these factors. I begin by temporarily setting aside the questions of tax losses and risk and consider what has happened over the past thirty years to 
the marginal tax rates for corporations on equity-financed investments in several classes of assets. The results enable one to compute not only aggregate marginal tax rates but also those faced by different industries. The differing incentives faced by these industries to invest in various assets result in a production distortion, which is estimated using the calculated tax-rate series.

In succeeding sections, I analyze how these basic results are affected by a more realistic treatment of risk and the asymmetric tax treatment of gains and losses and how, in the presence of personal taxes and the corporate financial decision, inflation affects the incentive to invest. Finally, an estimate is made of the extent to which accelerated depreciation has led to a reduction in the market value of corporate capital, relative to its replacement cost, as a result of the deferred taxes faced by older assets. This phenomenon is important not only when interpreting trends in corporate tax receipts but also in the evaluation of tax reform proposals that would alter the relative treatment of old and new assets.

\section{Measuring Effective Tax Rates on Corporate Capital}

In this section the focus is on the problem of determining marginal tax rates on prospective investments. The procedure is to use information on the actual composition of business fixed investment in the United States, estimated economic depreciation rates, and the tax law in each year, to derive the effective tax rates faced by individual investments in each year. These can then be aggregated to obtain overall effective tax rates. Because the focus is on fixed capital, the problem posed by the existence of noncapital income on corporate returns is eliminated. Because each vintage of assets is considered independently, the problem of aggregating vintage does not occur. The calculations assume that the relative price of capital goods and the tax rate are constant. The assumption that future tax changes are zero or are not anticipated has been the standard assumption in many related studies, so the calculations here are comparable to those of others. ${ }^{12}$

12. Studies that have calculated effective tax rates using this methodology include Charles Hulten and James Robertson, "Corporate Tax Policy and Economic Growth: An Analysis of the 1981 and 1982 Tax Acts" (Washington, D.C.: Urban Institute, 1982), and Mervyn King and Don Fullerton, eds., The Taxation of Income from Capital: A Compar- 
The basic formula used in these calculations is the well-known HallJorgenson user cost of capital, which gives the cost of a unit of capital services (under the assumption that the tax law will remain fixed) as:

$$
c=q(r+\delta)(1-k-u z) /(1-u)
$$

where

$$
\begin{aligned}
q= & \text { relative price of capital goods } \\
r= & \text { real rate of return the firm must earn after corporate taxes } \\
\delta= & \text { exponential rate at which the capital good decays } \\
k= & \text { investment tax credit } \\
u= & \text { corporate tax rate and } \\
z= & \text { present value of depreciation allowances obtained by discount- } \\
& \text { ing nominal depreciation allowances at } r+\pi, \text { the nominal rate }, \\
& \text { where } \pi \text { is the inflation rate. }
\end{aligned}
$$

Equation 1 implicitly assumes the use of equity finance, for if debt finance were used, $r$ itself would depend on the tax rate $u$ because of the deductibility of interest payments. If one introduces $b$, the fraction of the investment a firm finances with debt, at a nominal interest rate, $i$, and denotes the required nominal return to equity holders by $e$, it can be shown that ${ }^{13}$

$$
r=b i(1-u)+(1-b) e-\pi .
$$

At the margin, the firm earns zero profits after tax, in present value, if it invests until the marginal product of capital equals $c$. The effective corporate tax rate can be defined by asking what rate of tax, $\tau$, on the corporation's true economic income would present the same incentive to invest, for a given rate $r$ and the actual combination of $u, k$, and $z$. Under a pure income tax, depreciation allowances would equal economic depreciation, and the investment tax credit would equal zero. Since economic depreciation per dollar of investment equals $(1-\delta)^{t} \delta, t$ years after the asset's purchase, the present value of such allowances would

ative Study of the U.S., U.K., Sweden and West Germany (National Bureau of Economic Research, forthcoming). The first of these studies, like this one, looks only at taxes at the corporate level, while the second also includes the effects of corporate interest deductibility and personal taxes.

13. See Alan J. Auerbach, "Wealth Maximization and the Cost of Capital," Quarterly Journal of Economics, vol. 93 (August 1979), pp. 433-46. 
be $\delta /(r+\delta)$, and hence $\tau$ would be defined implicitly by the expression

$$
c=q\left(\frac{r}{1-\tau}+\delta\right),
$$

where $c$ is defined as in equation 1. Combining 1 and 3 yields the solution for $\tau$,

$$
\tau=\frac{c / q-(r+\delta)}{c / q-\delta}=\frac{(r+\delta)(1-k-u z)-(r+\delta)(1-u)}{(r+\delta)(1-k-u z)-\delta(1-u)} .
$$

Equation 4 is applied to historical data to determine the effective tax rates over time. The data come from various empirical sources and assumptions. For each asset, it is assumed that the depreciation practice followed was the most advantageous available to the investor in the year of investment. This rules out the use of straight-line depreciation in a year when, say, double-declining balance depreciation was available. Although there is evidence that not all businesses immediately switch to newly provided accelerated depreciation options, incorporating such behavior in the calculations is difficult without a more general model capable of explaining it. ${ }^{14}$ The detailed assumptions, depreciation methods, and lifetimes are discussed in appendix A. The asset categories are those for nonresidential investment used in national income account calculations. The real economic depreciation rate, $\delta$, used for each asset category comes from calculations based on patterns of price declines in asset resale markets. ${ }^{15}$

To calculate $\tau$ one also needs to know the real discount rate, $r$, and the inflation rate, $\pi$. Future values of $\pi$ needed for the calculations of $z$ are set equal in each year to those predicted from an ARIMA forecast

14. For evidence see Terence J. Wales, "Estimation of an Accelerated Depreciation Learning Function," Journal of American Statistical Association, vol. 61 (December 1966), pp. 995-1009; and Thomas Vasquez, "The Effects of the Asset Depreciation Range System on Depreciation Practices,' Paper 1 (U.S. Treasury, Office of Tax Analysis, May 1974).

15. These depreciation rates are presented in Dale W. Jorgenson and Martin A. Sullivan, "Inflation and Corporate Capital Recovery," in Charles R. Hulten, ed., Depreciation, Inflation, and the Taxation of Income from Capital (Washington, D.C.: Urban Institute, 1981), pp. 171-237. Most of the depreciation rates were originally calculated and presented by Charles R. Hulten and Frank C. Wykoff, "The Measurement of Economic Depreciation," in Hulten, ed., Depreciation, Inflation, and the Taxation of Income from Capital, pp. 81-125. 
based on lagged values of the inflation rate. Somewhat arbitrarily, $r$ is set at 4 percent.

Shown in table 3 are the thirty-four asset categories for which effective tax rates are calculated, along with their estimated rates of economic depreciation. Table 4 shows the historical series for the effective tax rates for two representative assets, industrial equipment and structures, in addition to the total annual rates, derived by weighting according to the composition of the capital stock.

Table 4 clearly shows the effects of both legislated tax changes and inflation. During the 1976-78 period, for example, there were no changes in the tax law. However, as inflation declined and then increased, so did effective tax rates. The same effect is evident between 1979 and 1980 . The general results are consistent with time-series estimates of the type done by Hulten and Robertson. ${ }^{16}$ Even before 1981 the net effects of inflation and the tax law had been to keep tax rates during the 1970s, overall, at levels comparable to (or lower than) those in the mid-1960s. Adding the 1950s and the period from 1981 to 1982 leads to an overall picture of declining rates, a trend that is weaker than the decline in revenues in table 1 but stronger than that of the average effective tax rates in table 2 , which are comparable in ignoring interest deductibility. This demonstrates the importance of looking at marginal tax rates.

The overall trend in aggregate tax rates masks a very strong shift between structures and equipment that is typified by the two assets in table 4. From 1953 through 1961 structures were relatively favored. Since then, almost all tax incentives have been aimed at equipment; the widening gap in effective tax rates was curbed somewhat in 1982, when the partial basis adjustment for the investment tax credit was introduced. This also served to remove, for the most part, the negative tax rates enjoyed by equipment in general. This possibility of negative tax rates merely reflects the fact that tax incentives can be so great as to lead investors to require a lower return before tax than after tax.

Effective tax rates by industry also have varied substantially over the years. The 1982 values for each of forty-four corporate industries are shown in table 5 . The rates range from a maximum of 39.4 percent to a minimum of 6.3 percent. The importance of such interindustry distortions is discussed below.

16. Hulten and Robertson, "Corporate Tax Policy and Economic Growth." 
Table 3. Asset Categories and Depreciation Rates

Percent

\begin{tabular}{|c|c|c|c|}
\hline $\begin{array}{l}\text { Category } \\
\text { number }\end{array}$ & Asset category & $\begin{array}{l}\text { Depreciation } \\
\text { rate }\end{array}$ & $\begin{array}{c}\text { Percentage } \\
\text { of } 1978 \\
\text { corporate } \\
\text { investment }\end{array}$ \\
\hline 1. & Furniture and fixtures & 11.00 & 2.7 \\
\hline 2. & Fabricated metal products & 9.17 & 1.7 \\
\hline 3. & Engines and turbines & 7.86 & 0.7 \\
\hline 4. & Tractors & 16.33 & 1.5 \\
\hline 5. & Agricultural machinery & 9.71 & 0.2 \\
\hline 6. & Construction machinery & 17.22 & 3.3 \\
\hline 7. & Mining and oil field machinery & 16.50 & 1.2 \\
\hline 8. & Metalworking machinery & 12.25 & 3.5 \\
\hline 9. & Special industry machinery & 10.31 & 2.9 \\
\hline 10. & General industrial equipment & 12.25 & 4.1 \\
\hline 11. & $\begin{array}{l}\text { Office, computing, and } \\
\text { accounting machinery }\end{array}$ & 27.29 & 4.7 \\
\hline 12. & Service industry machinery & 16.50 & 1.8 \\
\hline 13. & Electrical machinery & 11.79 & 10.4 \\
\hline 14. & Trucks, buses, and trailers & 25.37 & 11.9 \\
\hline 15. & Automobiles & 33.33 & 4.8 \\
\hline 16. & Aircraft & 18.33 & 1.7 \\
\hline 17. & Ships and boats & 7.50 & 0.8 \\
\hline 18. & Railroad equipment & 6.60 & 1.7 \\
\hline 19. & Instruments & 15.00 & 4.5 \\
\hline 20. & Other equipment & 15.00 & 1.5 \\
\hline 21. & Industrial buildings & 3.61 & 6.3 \\
\hline 22. & Commercial buildings & 2.47 & 7.3 \\
\hline 23. & Religious buildings & 1.88 & 0.0 \\
\hline 24. & Educational buildings & 1.88 & 0.0 \\
\hline 25. & Hospital buildings & 2.33 & 0.1 \\
\hline 26. & Other nonfarm buildings & 4.54 & 0.4 \\
\hline 27. & Railroads & 1.76 & 0.5 \\
\hline 28. & Telephone and telegraph facilities & 3.33 & 2.8 \\
\hline 29. & Electric light and power & 3.00 & 7.1 \\
\hline 30. & Gas & 3.00 & 1.1 \\
\hline 31. & Other public utilities & 4.50 & 0.3 \\
\hline 32. & Farm & 2.37 & 0.1 \\
\hline 33. & Mining, exploration, shafts, and wells & 5.63 & 6.1 \\
\hline 34. & Other nonbuilding facilities & 2.90 & 0.5 \\
\hline
\end{tabular}

Source: Dale W. Jorgensen and Martin A. Sullivan, "Inflation and Corporate Capital Recovery," in Charles R. Hulten, ed., Depreciation, Inflation, and the Taxation of Income from Capital (Washington, D.C.: Urban Institute, 1981), p. 179. 
Table 4. Effective Tax Rates for Equipment and Structures, 1953-82

Percent

\begin{tabular}{|c|c|c|c|}
\hline Year & $\begin{array}{c}\text { General } \\
\text { industrial } \\
\text { equipment }\end{array}$ & $\begin{array}{l}\text { Industrial } \\
\text { structures }\end{array}$ & All assets \\
\hline 1953 & 64.1 & 55.6 & 58.8 \\
\hline 1954 & 61.0 & 52.3 & 55.5 \\
\hline 1955 & 58.2 & 50.6 & 53.5 \\
\hline 1956 & 59.3 & 51.3 & 54.3 \\
\hline 1957 & 60.2 & 51.9 & 55.0 \\
\hline 1958 & 60.9 & 52.3 & 55.6 \\
\hline 1959 & 59.7 & 51.5 & 54.6 \\
\hline 1960 & 60.4 & 52.0 & 55.1 \\
\hline 1961 & 58.8 & 51.0 & 53.9 \\
\hline 1962 & 40.3 & 49.1 & 43.3 \\
\hline 1963 & 41.5 & 49.6 & 44.0 \\
\hline 1964 & 27.4 & 47.1 & 37.2 \\
\hline 1965 & 26.1 & 45.5 & 35.7 \\
\hline 1966 & 27.4 & 45.8 & 36.5 \\
\hline 1967 & 49.4 & 46.6 & 45.5 \\
\hline 1968 & 37.0 & 51.5 & 43.5 \\
\hline 1969 & 41.0 & 52.7 & 45.8 \\
\hline 1970 & 53.5 & 52.0 & 49.7 \\
\hline 1971 & 53.2 & 51.2 & 49.1 \\
\hline 1972 & 16.4 & 51.2 & 32.9 \\
\hline 1973 & 14.4 & 50.9 & 31.8 \\
\hline 1974 & 18.3 & 51.5 & 33.9 \\
\hline 1975 & 24.1 & 52.6 & 37.0 \\
\hline 1976 & 26.4 & 53.1 & 35.1 \\
\hline 1977 & 21.2 & 52.1 & 32.0 \\
\hline 1978 & 23.2 & 52.4 & 33.2 \\
\hline 1979 & 19.0 & 50.3 & 30.1 \\
\hline 1980 & 22.0 & 50.8 & 31.9 \\
\hline 1981 & -6.8 & 41.7 & 17.7 \\
\hline 1982 & 8.4 & 42.1 & 24.6 \\
\hline
\end{tabular}

Source: Author's calculations as discussed in the text.

\section{The Distortionary Impact of Differential Corporate Taxation}

One of the impressive facts about the effective tax rates in table 4 is how much, in any given year, they vary across investments. Since the seminal work of Harberger, there has been much concern about the 
Table 5. Effective Tax Rates, by Industry, 1982

Percent

\begin{tabular}{|c|c|c|}
\hline $\begin{array}{l}\text { Industry } \\
\text { number }\end{array}$ & Category & $\begin{array}{l}\text { Tax } \\
\text { rate }\end{array}$ \\
\hline 1. & Food and kindred products & 27.0 \\
\hline 2. & Tobacco manufactures & 24.3 \\
\hline 3. & Textile mill products & 22.8 \\
\hline 4. & Apparel and other fabricated textile products & 25.3 \\
\hline 5. & Paper and allied products & 18.3 \\
\hline 6. & Printing, publishing, and allied industries & 28.1 \\
\hline 7. & Chemicals and allied products & 20.1 \\
\hline 8. & Petroleum and coal products & 33.2 \\
\hline 9. & Rubber and miscellaneous plastic products & 19.8 \\
\hline 10. & Leather and leather products & 27.4 \\
\hline 11. & Lumber and wood products, except furniture & 25.3 \\
\hline 12. & Furniture and fixtures & 28.6 \\
\hline 13. & Stone, clay, and glass products & 24.6 \\
\hline 14. & Primary metal industries & 26.0 \\
\hline 15. & Fabricated metal industries & 23.3 \\
\hline 16. & Machinery except electrical & 24.6 \\
\hline 17. & Electrical machinery, equipment, and supplies & 24.7 \\
\hline 18. & Transportation equipment, except motor vehicles and ordnance & 30.4 \\
\hline 19. & Motor vehicles, and motor vehicle equipment & 21.3 \\
\hline 20. & Professional photographic equipment and watches & 27.0 \\
\hline 21. & Miscellaneous manufacturing industries & 25.8 \\
\hline 22. & Agricultural production & 16.8 \\
\hline 23. & Agricultural services, horticultural services, forestry and fisheries & 14.7 \\
\hline 24. & Metal mining & 34.3 \\
\hline 25. & Coal mining & 19.1 \\
\hline 26. & Crude petroleum and natural gas extraction & 32.2 \\
\hline 27. & Nonmetallic mining and quarrying, except fuel & 15.6 \\
\hline 28. & Construction & 13.1 \\
\hline 29. & Railroads and railway express service & 21.4 \\
\hline 30. & Street railway, bus lines, and taxicab service & 10.0 \\
\hline 31. & Trucking service, warehousing, and storage & 14.7 \\
\hline 32. & Water transportation & 6.3 \\
\hline 33. & Air transportation & 11.5 \\
\hline 34. & Pipelines, except natural gas & 22.9 \\
\hline 35. & Services incidental to transportation & 17.1 \\
\hline 36. & Telephone, telegraph, and miscellaneous communication services & 19.7 \\
\hline 37. & Radio broadcasting and television & 25.8 \\
\hline 38. & Electric utilities & 25.0 \\
\hline 39. & Gas utilities & 20.0 \\
\hline 40. & Water supply, sanitary services, and other utilities & 39.4 \\
\hline 41. & Wholesale trade & 18.7 \\
\hline 42. & Retail trade & 27.5 \\
\hline 43. & Finance, insurance, and real estate & 37.3 \\
\hline 44. & Services & 23.9 \\
\hline
\end{tabular}

Source: Author's calculations. Tax rates for other years are available from the author upon request. 
losses caused by the misallocation of capital between the corporate and noncorporate sectors, particularly housing. ${ }^{17}$ Relatively less emphasis has been placed until recently on the massive distortions across industries, and within any given industry in the corporate sector. In part because of the complex way in which personal taxes interact with corporate taxes (discussed below), it is not clear that corporate investment faces a substantially higher overall tax rate than noncorporate investment. Thus distortions within the corporate sector may be as important as distortions between that sector and other sectors, and reform of the corporate tax should recognize this.

Little empirical work has been done on the losses due to differential taxation within the corporate sector. This is not surprising, given that it would require knowledge of elasticities of substitution among different types of capital and labor in production in each corporate industry, about which there is very little evidence. To provide some insight into this question, therefore, I examine the losses imposed by the corporate tax under what have come to be fairly standard "baseline" assumptions: that each industry has a production function that is Cobb-Douglas in each type of capital used and labor, and that capital is allocated so as to equate the real after-tax return across investments. This latter assumption makes it appropriate to regard the losses as long run. Under these assumptions it is possible to derive an analytic expression for and compute the loss; in particular, for the vector of outputs being produced by the corporate sector, one can calculate how much of the existing capital stock could be disposed of if the remaining capital were allocated optimally.

The analytic expression for this measure of the welfare cost of differential corporate taxation is derived in appendix B. It contains two components, each of which is nonnegative. The first, which expresses the distortion due to differential taxation within industries, is zero only when there is uniform taxation within each industry. The second, which expresses the distortion due to differential taxation between industries, is zero only when the weighted geometric means of the before-tax rates of return in each industry are the same. The measure derived here is

17. Arnold C. Harberger, "Efficiency Effects of Taxes on Income from Capital," in Marian Krzyzaniak, ed., Effects of the Corporation Income Tax (Wayne State University Press, 1966), pp. 107-17. 
related to that obtained by Gravelle, who also used the Cobb-Douglas assumption but aggregated the corporate sector into a single industry. ${ }^{18}$

When this technique is used to determine the asset-specific effective tax rates, it yields the series in table 6 for the fraction of the capital stock effectively wasted under the long-run allocation of capital according to the effective tax rates prevailing in a given year.

These distortions show no downward trend, despite the steady decline in corporate tax collections. On the contrary, the overall loss has exceeded 1.54 percent since 1972, whereas it was never as high before. The two components of the total distortion have generally moved together, with the "within" component accounting for about four-fifths of the distortion. Major increases in the degree of distortion occurred in 1964, with the repeal of the Long Amendment, and in 1971, with the introduction of the Asset Depreciation Range. A smaller increase was associated with the 1981 legislation, while the basis adjustment instituted in 1982 substantially lowered the estimated distortion. The 1981 distortion implies, for instance, that 3.19 percent of the 1981 net corporate capital stock of 2.05 trillion dollars was being wasted in that year. ${ }^{19}$ At a before-tax return of 8 percent, this would mean a loss of over $\$ 5$ billion in 1981. It should be emphasized that this measure does not take into account the change in mix of outputs within the corporate sector and the relative levels of production in the corporate and noncorporate sectors that could be expected to flow from the tax inequalities. Such changes would increase the welfare loss.

\section{Tax Losses under the Corporate Tax}

Over the years, as depreciation schedules have become more accelerated, more firms have found themselves without taxable income against

18. Jane G. Gravelle, "The Social Cost of Nonneutral Taxation: Estimates for Nonresidential Capital," in Hulten, ed., Depreciation, Inflation, and the Taxation of Income from Capital, pp. 239-50. Her measure also differs in the use of a Cobb-Douglas function for gross rather than net output. Although the former approach may be conceptually more appealing, only the latter allows a closed-form solution in the multi-industry case. This difference helps explain why the estimate of excess burden in this paper is somewhat higher for 1981: the elasticity of substitution is higher when the net CobbDouglas function is used.

19. John C. Musgrave, "Fixed Reproducible Tangible Wealth in the United States," Survey of Current Business, vol. 62 (October 1982), pp. 33-38. 
Table 6. The Welfare Cost of Differential Corporate Taxation, 1953-82

Percent of capital stock

\begin{tabular}{|c|c|c|c|}
\hline Year & $\begin{array}{l}\text { Distortion } \\
\text { within } \\
\text { industries }\end{array}$ & $\begin{array}{l}\text { Distortion } \\
\text { between } \\
\text { industries }\end{array}$ & $\begin{array}{c}\text { Total } \\
\text { distortion }\end{array}$ \\
\hline 1953 & 0.59 & 0.13 & 0.72 \\
\hline 1954 & 0.53 & 0.11 & 0.64 \\
\hline 1955 & 0.37 & 0.07 & 0.45 \\
\hline 1956 & 0.43 & 0.09 & 0.52 \\
\hline 1957 & 0.48 & 0.10 & 0.58 \\
\hline 1958 & 0.51 & 0.11 & 0.62 \\
\hline 1959 & 0.45 & 0.09 & 0.54 \\
\hline 1960 & 0.49 & 0.10 & 0.59 \\
\hline 1961 & 0.40 & 0.08 & 0.48 \\
\hline 1962 & 0.45 & 0.12 & 0.57 \\
\hline 1963 & 0.41 & 0.11 & 0.52 \\
\hline 1964 & 1.11 & 0.29 & 1.40 \\
\hline 1965 & 1.01 & 0.26 & 1.27 \\
\hline 1966 & 0.94 & 0.24 & 1.18 \\
\hline 1967 & 0.25 & 0.04 & 0.29 \\
\hline 1968 & 0.82 & 0.21 & 1.03 \\
\hline 1969 & 0.62 & 0.16 & 0.78 \\
\hline 1970 & 0.27 & 0.05 & 0.33 \\
\hline 1971 & 0.27 & 0.05 & 0.32 \\
\hline 1972 & 2.95 & 0.69 & 3.64 \\
\hline 1973 & 3.17 & 0.74 & 3.90 \\
\hline 1974 & 2.74 & 0.64 & 3.38 \\
\hline 1975 & 2.18 & 0.50 & 2.69 \\
\hline 1976 & 2.13 & 0.57 & 2.70 \\
\hline 1977 & 2.69 & 0.71 & 3.40 \\
\hline 1978 & 2.40 & 0.64 & 3.04 \\
\hline 1979 & 2.52 & 0.67 & 3.19 \\
\hline 1980 & 2.23 & 0.59 & 2.83 \\
\hline 1981 & 2.64 & 0.55 & 3.19 \\
\hline 1982 & 1.29 & 0.25 & 1.54 \\
\hline
\end{tabular}

Source: Author's calculations as described in appendix B.

which to claim deductions. This is easy to understand. Under the current tax law, an investor purchasing an asset in the five-year capital recovery class receives an immediate deduction of 15 percent, a deduction of 22 percent after one year (both on a basis equal to 95 percent of purchase price), and an immediate investment tax credit. Gross receipts in the first year of at least 56.9 cents per invested dollar, that is, $(15+22) \times$ $0.95+10 / 0.46$, would be required to absorb these tax benefits, even 
without accounting for the fact that investment credits cannot be used to offset all taxable income. Firms without substantial existing sources of income and fast-growing firms are likely to have to carry losses back or forward. Carrying losses forward, however, essentially offsets the benefits of accelerated depreciation. This problem provided an impetus for the introduction of "safe-harbor" leasing under the 1981 tax act. To understand why this process was structured as it was and also why it was so unpopular, it helps to review why the current tax system discriminates against tax losses.

Aside from the enforcement problems mentioned above, the lack of a loss offset in the tax system possibly derives in part from a perception among policymakers that losing firms are just that: "losers." For some reasons, the stockholders of such firms are unable to replace poor management or, for some other reason, the helping hand of government is necessary to discourage such firms. The benefit of having carry-back and carry-forward provisions, so this argument continues, is that successful, risk-taking firms with an occasional "bad draw" would lose little or nothing, while those with more permanent problems would benefit less from these provisions.

Aside from the questionable economic merit in discriminating among firms by the state of their income, there are at least two additional problems with this approach. First, even if "losers" are initially discouraged from investing because of the prospect of nonrefundable losses, once these losses have occurred, the desire to use them up through carrying forward may offer an increased incentive to invest in the future in order to generate higher expected taxable income. Second, under a tax that does not have economic income as its base, there need be no systematic relation between a firm's taxable income and its underlying profitability. Indeed, under accelerated depreciation it is the firms whose capital stocks are growing fast that face the severest problem. ${ }^{20}$

"SAFE-HARBOR" LEASING AS A SOLUTION

For years before 1981, leasing was recognized as a method for transferring tax benefits among firms. That many airlines leased some or

20. These issues are explored more fully in Alan J. Auerbach, "The Dynamic Effects of Tax Law Asymmetries," Working Paper 1152 (National Bureau of Economic Research, June 1983). 
all of their planes from financial institutions was well known. By making payments to the lessor over the period of the lease timed to coincide better with the income from the project, the lessee could obtain a greater part of the value of the tax benefits, which would be transferred by the lessor in the form of reduced lease payments.

But leasing could only be used for certain assets, essentially those that could be used by a firm other than the lessee at the expiration of the lease: planes, but not dies used to make cars of a particular model. Moreover, there were other provisions that prohibited lessee finance or a fixed repurchase price option and required a "reasonable" profit for the lessor before tax, which made leases imperfect as a transfer mechanism.

Most of these hindrances were removed in 1981, and the result was a spate of "wash leases" under which cash changed hands only at the initiation of a lease, and the title to the asset in question never left the possession of the user. In this arrangement, the purchaser of the tax benefits (the lessor) received the investment tax credit and depreciation deductions in exchange for this initial "down payment," plus a stream of future tax liabilities. The transaction involved a paper loan by the lessee to make up the difference between the down payment and the full price of the asset. The tax obligations of the lessor reflected the fact that the paper lease payments received exceeded the paper interest payments by an amount equal to the principal repayments made to the lessee. In addition to the down payment, the lessee received a stream of future decreases in tax liability mirroring those of the lessor. ${ }^{21}$

Safe-harbor leasing was criticized and scheduled under the tax act of 1982 for repeal after 1983, to be replaced by yet another type of leasing that is referred to in the legislation as finance leasing. From initial inspection, finance leasing appears to be a hybrid of safe-harbor leasing and the pre-1981 leasing, often referred to as leveraged leasing. ${ }^{22}$ Much of the criticism took the form of declamations against "welfare for corporations," reflecting in part news stories relating the success of firms like General Electric Company in using leases to offset its current

21. Leasing is described more fully and a sample wash lease outlined in Auerbach, "The New Economics of Accelerated Depreciation."

22. The 1982 changes are discussed and analyzed in Alvin C. Warren, Jr., and Alan J. Auerbach, "Tax Policy and Equipment Leasing after TEFRA," Harvard Law Review, vol: 96 (May 1983), pp. 1579-98. 
income tax liability as well as those of previous years (through a carryback) and Occidental Petroleum Corporation's use of leasing to enable it to use foreign tax credits that otherwise would have expired. But perhaps the more fundamental problem with leasing was that it did not appropriately discriminate among investors.

To understand this problem, it is helpful to define three extreme types of investor: the company with taxable profits now and for the forseeable future (the taxable company), the company with a substantial current tax loss being carried forward and little prospect for being taxable in the future (the tax-exempt company), and the company undertaking large initial investments that generate large current deductions and credits that cannot be used, but with the prospect of taxable income in the near future (the start-up company). ${ }^{23}$ First, consider the case in which no deductions are generated by the use of debt finance.

Under the Accelerated Cost Recovery System, the taxable investor purchasing an asset in the five-year capital recovery class in 1981 obtained, in effect, a negative tax rate on that asset: as shown in table 4 , the present value of the investment tax credit and depreciation allowances from that cost recovery system slightly exceeded those that would have been available if immediate expensing were allowed for tax purposes. For the start-up firm, however, this was not the case. By having to carry forward unused credits and deductions, the benefits of acceleration were lost. By engaging in a lease, the start-up company could receive the full benefits, through the immediate down payment and the future tax deductions, timed to occur after the company had become taxable. But tax-exempt firms could engage in leases, too, and did so. Because such firms were facing roughly the same incentives to invest as the taxable firms, the receipt of the initial down payment appeared to provide them with a substantial benefit. Given down payments under five-year leases in the neighborhood of 20 cents per dollar of investment, this was an important issue.

Once debt finance is taken into account, however, these results are altered. In particular, the tax-exempt firms face the additional disadvantage of not being able to deduct interest payments. Calculations by Warren and Auerbach suggest that, for firms using all debt finance at the

23. The following discussion draws on the arguments in Alvin C. Warren, Jr., and Alan J. Auerbach, "Transferability of Tax Incentives and the Fiction of Safe Harbor Leasing,"' Harvard Law Review, vol. 95 (June 1982), pp. 1752-86. 
margin, leasing as structured under the 1981 act would have been inadequate to reduce the user cost of capital to that of the taxable corporation. ${ }^{24}$

\section{THE IMPACT OF LOSSES ON THE INCENTIVE TO INVEST}

These taxable, start-up, and tax-exempt companies are extreme cases that exist only in papers such as this. In reality, each firm has a finite probability of being taxable in a particular year in the future, given its current and past experience. The discussion in this section seeks to determine how large an effect this has on the incentive to invest. The basic approach involves observing individual firms over time and estimating the probabilities of whether a firm will be taxable in a given year based on the experience of previous years, assuming the firm optimizes subject to a particular tax system. With such estimates, one can obtain the expected present value of taxes the firm will pay in connection with a new investment project, by translating the accrued tax liability (positive or negative) that the project generates in each year into a distribution of dates over which those taxes actually will be paid. Because I limit consideration to marginal projects that are assumed not to affect the firm's probabilities of being in a particular taxable position in a given year, this is a straightforward calculation. The calculations are based on observations of the tax loss carried forward by individual firms over time, inasmuch as data on annual accrued tax liabilities are not currently available.

Under current tax law, a firm with a tax loss may obtain a refund for this loss and hence be taxed as if there were a full-loss offset at the margin if the nominal value of its previous three years' taxable income is at least as large. Such losses are said to be carried back against previous income. A firm that has insufficient potential for carrying back can only carry excess current losses forward, in the hope that its nominal value can be offset against future taxable income. Losses can now be carried forward for as many as fifteen years; before 1981 they expired after seven years.

One may think of current taxable profits in a symmetric way. If, for example, the firm has a larger loss carried forward from previous years, the profits are set against the loss carried forward; the firm pays no taxes

24. Ibid. 
and carries forward any remaining loss to the next year. If the firm has a potential for loss carry-back in the form of previously taxed income, it pays taxes on its current income and adds it to the potential carry-back that it has available in the following year.

One may summarize the firm's current tax status by a continuous variable, $y_{t}$, equal to the real value of its tax loss carry-forward at the end of year $t$ when positive and, in absolute value, equal to the firm's potential loss carry-back when negative. Whether increments to a given year's tax liabilities are paid in year $t$ or some later year depends on the sign of $y_{t}$. If $y_{t}$ is negative, whatever additional taxes (positive or negative) the firm owes are paid in year $t$. If $y_{t}$ is positive, the firm neither receives additional benefits nor pays incremental taxes at the margin in year $t$. The additional liability (perhaps negative) is added to the previous loss carry-forward and is to be paid (in fixed nominal terms) in the first subsequent year when $y_{t}$ is negative. To calculate the expected present value of a particular dated tax liability one must therefore know the joint distribution of $y_{t}$ and its past and future values.

The modeling of $y_{t}$ is complicated because its relation to its own past values depends both on the tax law and the characteristics of the firm. One would expect substantial serial correlation in $y_{t}$ because the current year's taxable income or loss is likely to be small relative to the stock of losses carried forward or gains available for a potential carry-back. However, $y$ would tend to decay even with a zero current tax liability, for two reasons. First, since an unused carry-forward (or carry-back) is a nominal claim, its real value decays at the rate of inflation. Moreover, the expiration of carry-forwards and potential carry-backs imparts a further, vintage-related decay of $y$.

To the extent that a firm would normally expect positive taxable income in a given year, this will tend to lead over time to negative $y_{t}$. The evolution of $y_{t}$, starting at any initial value, depends not only on the tax law (with respect to depreciation allowances and so on) but also on the firm's overall level of profitability and the stochastic process generating its annual returns. Firms facing a loss carry-forward may alter their behavior to influence $y$ because the accrual of losses over time without interest provides an incentive to "use them up." 25

Because even a simple specification of the evolution of $y$ leads to a

25. This is discussed in Auerbach, "The Dynamic Effects of Tax Law Asymmetries." 
fairly complicated procedure for the derivation of the conditional probabilities needed for these calculations, I assume that all the effects just mentioned can be summarized by the first-order process,

$$
y_{t}=\alpha+\beta y_{t-1}+\epsilon_{t},
$$

where the tax loss carry-forward, $y_{t}$, is divided by a measure of the firm's assets to correct for potential heteroscedasticity. I use the estimated variance of $\epsilon_{t}$ along with the estimates of $\alpha$ and $\beta$ to generate distributions for $y_{t}$, conditional on its past value, under the assumption of normality. Using the estimated distribution of $y_{t}$ conditional on $y_{t-1}$, that of $y_{t-1}$ on $y_{t-2}$, and so forth, I can then generate the conditional probability that $y_{t}$ exceeds zero, given information on whether each of $y_{t-1}, y_{t-2}, \ldots$ exceeded zero. The distribution of actual tax payments deriving from a tax liability, $T_{t}$, dated year $t$ then equals ${ }_{t} p_{0} \times T_{t}$ in year $t,{ }_{t+1} p_{10} \times T_{t}$ $\left(1-\pi_{t+1}\right)$ in year $t+1,{ }_{t+2} p_{110} \times T_{t}\left(1-\pi_{t+1}\right)\left(1-\pi_{t+2}\right)$ in year $t+2$, and so on, where ${ }_{t} p_{0}$ is the unconditional probability of being taxable in year $t, \pi_{t}$ is the inflation rate in year $t$, and ${ }_{t+\mathrm{i}} p_{1, \ldots 10}$ is the probability that $y_{t+i}<0$, conditional on $y_{t}, y_{t+i}, \ldots, y_{t+i-1}>0$. With a perfect loss offset, ${ }_{t} p_{0}$ would equal 1 , and the remaining probabilities would equal zero. Calculation of the time it takes for the probabilities $p_{0}, p_{10}, \ldots$ to converge to zero provides an estimate of how long a firm with a loss takes to pay its accrued taxes.

To estimate equation 5, I used the Compustat data file derived from a panel of large American corporations. The version of Compustat used contains data from 1959 to 1978. It is unfortunate that the variable $y$, which is defined here to be the tax loss carry-forward when positive and the potential carry-back when negative, is observed only when it is positive. That is, Compustat contains an annual observation for each firm on the tax loss carry-forward but nothing on the potential carryback. Construction of such a number would require information on the previous three years' taxable income, which is unavailable. Thus for many observations $y_{t}, y_{t-1}$, or both, are missing.

To obtain consistent estimates of $\alpha$ and $\beta$, the following technique is adopted. All observations for which $y_{t-1}$ is observed are selected and, using a standard Tobit procedure, equation 5 is estimated. From this, one can obtain predicted values of $y_{t}$ for all these observations, including those for which the actual value is not available. Adding observations on $y_{t+1}$, for which a predicted value of $y_{t}$ can now be used as the 
explanatory variable, I reestimated equation $5 .{ }^{26}$ For the first stage of the estimation 1,750 observations were available for 1959-77, with most occurring in the latter part of the sample. By the method just described, another 317 observations were added for the second stage of the estimation. The resulting equation is ${ }^{27}$

$$
\begin{gathered}
y_{t}=-0.063+0.729 y_{t-1} \\
(0.009)(0.023)
\end{gathered}
$$

Standard error of estimate $=0.348$,

where standard errors are in parentheses, and $y_{t}$ (when positive and observed) equals the firm's tax loss carry-forward divided by a corrected measure of its net capital stock. ${ }^{28}$ The coefficients $\alpha$ and $\beta$ conform to prior expectations that the former should be negative and the latter between zero and 1 . This combination yields a long-run value of $y_{t}$ that is negative and the decay of shocks away from it. The long-run value of $y_{t}$ implied by 6 is -0.232 ; the typical firm would have available a potential carry-back equal to 23.2 percent of its net capital stock. Given observed before-tax rates of return, this represents approximately two years of profit, a reasonable figure.

This long-run value, however, is simply the mean of a long-run distribution of $y_{t}$. It is the value to which $y_{t}$ would converge in the absence of shocks of above-average losses or gains. In fact, there will be a longrun probability distribution for $y_{t}$ around this value that depends on the magnitude of these shocks. By assuming that the annual random shock to $y_{t}$ is normally distributed, with a standard deviation equal to the standard error of estimate in 6 , one can calculate the long-run probability distribution for $y_{t}$. Using this long-run distribution, one can then calculate

26. The argument for doing so is that otherwise $\alpha$ and $\beta$ will be derived only from observations for which $y_{t-1}$ is positive. Any asymmetry in the equation connected with the sign of $y_{t-1}$ would not be discernible. In fact, this two-stage procedure, in principle, allows estimation of individual values of $\alpha$ and $\beta$ depending on the sign of $y_{t-1}$. Such an experiment proved unsuccessful, however, because the coefficients for negative values of $y_{t-1}$ were estimated with insufficient precision.

27. Because the two stages were estimated separately, these standard errors lack the adjustment necessary to account for the fact that some values of $y_{t-1}$ are estimated. However, given that such observations are a small part of the sample, and that the standard errors are so small relative to the coefficients, such a correction was not made here.

28. This capital-stock measure was calculated for the Compustat firms and is described by Clint Cummins, Bronwyn Hall, and Elizabeth Laderman in "The R\&D Master File: Documentation," August 1982. 
Table 7. The Persistence of Loss Carry-Forward: Estimated Long-Run Transition Probabilities ${ }^{\mathrm{a}}$

\begin{tabular}{cc||cc}
\hline $\begin{array}{c}\text { Number } \\
\text { of years }\end{array}$ & $\begin{array}{c}\text { Probability } \\
\text { that } y_{\mathrm{t}}>0\end{array}$ & $\begin{array}{c}\text { Number } \\
\text { of years }\end{array}$ & $\begin{array}{c}\text { Probability } \\
\text { that } y_{\mathrm{t}}>0\end{array}$ \\
\hline 0 & 0.6926 & 11 & 0.0033 \\
1 & 0.1041 & 12 & 0.0025 \\
2 & 0.0599 & 13 & 0.0019 \\
3 & 0.0397 & 14 & 0.0014 \\
4 & 0.0277 & 15 & 0.0011 \\
5 & 0.0199 & 16 & 0.0008 \\
6 & 0.0144 & 17 & 0.0006 \\
7 & 0.0105 & 18 & 0.0005 \\
8 & 0.0077 & 19 & 0.0003 \\
9 & 0.0058 & 20 & 0.0010 \\
10 & 0.0044 &
\end{tabular}

Source: Author's calculations as described in the text. The value shown for each year is the unconditional probability that a representative firm will have a tax loss carried forward for exactly this number of successive years. a. The last probability equals the sum of all remaining values. It is assumed in these calculations that losses cannot occur for more than twenty successive years.

(using a numerical integration technique) the probabilities $p_{0}, p_{10}, p_{110}$, and so on, as defined above: the unconditional probability of a firm being taxable in a given year, the probability of it being taxable following a loss carry-forward, following two years of loss carry-forwards, and so forth. These probabilities are presented in table 7. Even though the expected long-run value of $y_{t}$ is negative, over 30 percent of the long-run distribution of $y_{t}$ is positive. An important feature of the distribution is that it predicts that a tax obligation accrued in a given year would be paid, on average, 1.055 years later.

With these probabilities, one can estimate the effect of the asymmetric treatment of losses on the incentive to invest. This is done by first positing a certain before-tax internal rate of return on an asset and an economic depreciation rate. With these, a time pattern of marginal products for the asset can be generated. It is assumed that these returns are certain. Then, with a hypothesized pattern of depreciation allowances and investment tax credits, one can calculate the pattern of accrued tax liabilities generated by the asset over its lifetime. These are then converted into an expected tax payment pattern using the probabilities in table 7 and an assumed inflation rate. The latter is necessary because tax liabilities are carried forward in nominal terms, and these liabilities decay in real terms through inflation. Finally, one can calculate the internal rate of return for the firm's expected after-tax flows. Comparing 
Table 8. Effective Tax Rates for Equipment and Structures: The Importance of Deferred Payment ${ }^{a}$

Percent

\begin{tabular}{|c|c|c|c|c|}
\hline \multirow[b]{2}{*}{$\begin{array}{l}\text { Tax law and } \\
\text { inflation rate }\end{array}$} & \multicolumn{2}{|c|}{$\begin{array}{c}\text { General industrial } \\
\text { equipment }\end{array}$} & \multicolumn{2}{|c|}{$\begin{array}{l}\text { Industrial } \\
\text { structures }\end{array}$} \\
\hline & $\begin{array}{c}\text { Immediate } \\
\text { payment } \\
p_{0}=1\end{array}$ & Actual & $\begin{array}{c}\text { Immediate } \\
\text { payment } \\
p_{0}=1\end{array}$ & Actual \\
\hline 1965 tax law & & & & \\
\hline No inflation & 13 & 22 & 38 & 37 \\
\hline 4 percent & 33 & 37 & 52 & 47 \\
\hline 8 percent & 48 & 47 & 58 & 52 \\
\hline 1972 tax law & & & & \\
\hline No inflation & 8 & 18 & 40 & 38 \\
\hline 4 percent & 27 & 33 & 55 & 50 \\
\hline 8 percent & 42 & 43 & 62 & 55 \\
\hline 1982 tax law & & & & \\
\hline No inflation & -13 & 10 & 27 & 27 \\
\hline 4 percent & 0 & 18 & 38 & 37 \\
\hline 8 percent & 12 & 25 & 45 & 42 \\
\hline
\end{tabular}

Source: Author's calculations as described in the text.

a. Tax rates labeled $p_{0}=1$ assume that tax payment occurs when liability is accrued; those labeled actual are based on table 7 , using the method described in the text.

this to the assumed before-tax return using equation 4 yields, as before, a value for $\tau$, the effective tax rate. ${ }^{29}$

These rates are presented in table 8 for two representative assets, industrial structures and general industrial equipment. A before-tax real return of 6 percent is assumed, and the economic depreciation rates listed in table 3 ( 0.0361 and 0.1225 , respectively) are used. Estimates are given of $\tau$ for the tax laws of the mid-1960s, of the early 1970s, of the present period, and for inflation rates of zero, 4 , and 8 percent. Also presented are the effective tax rates, comparable to those in table 4 , based on the assumption that taxes are paid when the liability is accrued.

It should be kept in mind that the estimates on which the probabilities are based come from a reduced-form equation that would not necessarily be stable over changes in tax regime or economic environment. The

29. These calculations are based on a fixed before-tax return, rather than those above, which started with the after-tax return and generated a before-tax return. The difference lies only in that the overall level at which the two rates are compared will normally differ.

A second point about $\tau$ is that it implicitly assumes risk neutrality with respect to the risky tax payments. This makes sense if the risk is entirely diversifiable. Otherwise, additional corrections of the type discussed in the next section are necessary. 
value of $p_{0}$, for example, will undoubtedly be lower in the 1980 s because of the tax changes enacted in 1981. Thus estimates of the impact of losses for 1982 probably understate their actual importance. However, one can view the results as illustrations of the general magnitude of the effect that loss carry-forwards and carry-backs may have.

Table 8 contains many interesting results. First, it shows that tax rates are less sensitive to inflation once tax deferral has been taken into account. Moreover, tax deferral lowers effective tax rates for structures, but generally raises them for equipment. To understand this, it helps to consider separately the tax liabilities generated by gross rents and the benefits generated by depreciation deductions. The deferral of tax payments through losses benefits the firm, but the deferral of deductions hurts it. It is possible that either effect can dominate. The larger the depreciation allowances relative to gross income, the more likely it is that their deferral will outweigh deferral of tax payments and lead to a net increase in tax rates. In general, the lower the effective tax rate, the more likely it is that deferral will raise it. This is evident at zero inflation from a comparison of the values for the representative equipment and structure and is reinforced by the relative impact of inflation, which lowers the value of depreciation allowances an asset receives.

These calculations indicate how a typical firm will be affected by the carry-forward and carry-back provisions of the tax law in the long-run. In any year, however, each firm will have a different tax history and, in the terminology here, a different value of $y_{t}$. That firms face the same incentives in the long run should not be confused with the fact that a firm with a large loss carry-forward faces very different incentives than one with a large potential carry-back. To quantify the importance of this difference, I generated the matrices of annual loss probability distributions, one for a firm with an initial value of $y_{t}$ that is one standard deviation below its long-run mean (a "high-tax" firm) and one with an initial value of $y_{t}$ that is one standard deviation above its long-run mean (a "low-tax" firm). After several years the entries in each matrix converge to the steady-state probabilities shown in table 7 . In the short run, however, actual history is very important.

Effective tax rates for these firms, comparable to the columns labeled actual in table 8 , are shown in table 9. The striking outcome in this table is that the firms with higher recent taxable profits, which are also more likely to be taxable in the near future (the high-tax firms) face lower 
Table 9. Effective Tax Rates: The Importance of Deferred Payment, by Taxable Status Percent

\begin{tabular}{|c|c|c|c|c|}
\hline \multirow{2}{*}{$\begin{array}{l}\text { Tax law and } \\
\text { inflation rate }\end{array}$} & \multicolumn{2}{|c|}{$\begin{array}{c}\text { General industrial } \\
\text { equipment }\end{array}$} & \multicolumn{2}{|c|}{$\begin{array}{l}\text { Industrial } \\
\text { structures }\end{array}$} \\
\hline & Low tax & High tax & Low tax & High tax \\
\hline \multicolumn{5}{|l|}{1965 tax law } \\
\hline No inflation & 17 & 12 & 37 & 37 \\
\hline 4 percent & 33 & 30 & 48 & 48 \\
\hline 8 percent & 47 & 43 & 53 & 53 \\
\hline \multicolumn{5}{|l|}{1972 tax law } \\
\hline No inflation & 12 & 7 & 40 & 38 \\
\hline 4 percent & 28 & 23 & 52 & 52 \\
\hline 8 percent & 40 & 35 & 57 & 57 \\
\hline \multicolumn{5}{|l|}{1982 tax law } \\
\hline No inflation & -3 & -15 & 27 & 25 \\
\hline 4 percent & 10 & -3 & 37 & 35 \\
\hline 8 percent & 20 & 5 & 42 & 42 \\
\hline
\end{tabular}

Source: Author's calculations as described in the text.

a. Tax rates labeled high tax assume an initial value of $y_{t}$ that is one standard deviation below long-run mean; those labeled low tax assume an initial value of $y_{t}$ that is one standard deviation above mean.

effective tax rates. This is because, in the early years when the differences among firms are greatest, accelerated depreciation allowances generate tax losses, especially for equipment. Being tax exempt in these years is a hindrance, not a help.

Thus the asymmetric treatment of gains and losses under the corporate tax may lower or raise taxes for the average firm and is, under recent and current tax law, most helpful for firms with a history of taxable profits.

\section{The Corporate Tax and Risk-Taking}

One of the fundamental reasons for the existence of public corporations is to allow risks to be efficiently diversified through the stock market. Various aspects of the corporate tax law influence risk-taking. Besides the discrimination against tax losses discussed above, the absence of indexing in the tax law means that uncertain inflation makes the value of depreciation deductions and nominal inventory profits uncertain. Uncertainties about future changes in the law themselves affect current decisions. However, much of the recent discussion has 
focused on the role of the corporate tax in sharing the private risks of corporations by collecting more revenue when profits are high and less when they are low. The existence of this risk-sharing has been understood since the seminal work of Domar and Musgrave and of Tobin, but the implications for the effective taxation of risky assets under general systems of taxation have not been fully developed. ${ }^{30}$

Suppose assets are risky both in their gross yield (before depreciation and taxes) and in the rate at which they depreciate. The current tax system does not absorb a proportion of the net yield (gross yield less depreciation) but rather a proportion of the gross yield less a predetermined allowance for depreciation. This has the effect of lessening the risk-sharing of the tax system because fluctuations in the net return that result from variations in the depreciation rate do not alter the assets' tax liability.

In appendix $\mathrm{C}$ it is shown that the effective tax rate on a risky investment, defined as before to be the rate of tax on economic income that would yield the same incentive to invest as the current tax system, is

$$
\tau=\frac{\left(y+\bar{\delta}+\alpha_{\delta}\right)(1-k-u z)-\left(y+\bar{\delta}+\alpha_{\delta}\right)(1-u)}{\left(y+\bar{\delta}+\alpha_{\delta}\right)(1-k-u z)-\left(\bar{\delta}+\alpha_{\delta}\right)(1-u)},
$$

where the real, after-tax return, $r$, has been replaced by the safe return, $y ; z$ is now calculated using this rate plus the inflation rate; $\bar{\delta}$ is expected economic depreciation; and $\alpha_{\delta}$ is the component of the risk premium required by investors because of the riskiness of economic depreciation. Increases in the riskiness of depreciation, through increases in $\alpha_{\delta}$, have the same effect on the firm's decisions as increases in the expected depreciation rate itself. Hence two assets that have the same overall risk premium in the absence of taxes, expected rate of depreciation, and depreciation allowances will normally face different effective tax rates, with the asset whose depreciation provides more of the overall asset risk being at a disadvantage. For this asset, the proportional tax on gross returns is of less value in the sharing of risks because the returns are not as risky.

30. See Evsey D. Domar and Richard A. Musgrave, "Proportional Income Taxation and Risk-Taking," Quarterly Journal of Economics, vol. 58 (May 1944), pp. 388-422; and James Tobin, "Liquidity Preference as Behavior Towards Risk," Review of Economic Studies, vol. 25 (February 1958), pp. 65-86. 
Table 10. Taxation and Risk: The Impact of Stochastic Returns on Effective Rates under the 1982 Tax Law

\begin{tabular}{ccc}
\hline & \multicolumn{2}{c}{ Effective tax rate } \\
\cline { 2 - 3 } $\begin{array}{c}\text { General } \\
\text { Capital } \\
\text { industrial }\end{array}$ & $\begin{array}{c}\text { Industrial } \\
\text { equipment } \\
\text { (percent) }\end{array}$ & $\begin{array}{c}\text { structures } \\
\text { (percent) }\end{array}$ \\
\hline 0.00 & -21.8 & 45.6 \\
0.02 & -25.6 & 53.2 \\
0.04 & -29.7 & 59.0 \\
0.06 & -34.1 & 63.5 \\
\hline
\end{tabular}

Source: Equation 7, with $y=0.02, \pi=0.06$, and $\delta$ taken from table 3 . Comparable values to table 4 , with $y=$ 0.04 and $\alpha_{\delta}=0$, are -0.3 percent and 39.7 percent, respectively.

Although there is much evidence on the risk-free rate of return, little is known about the stochastic processes generating the returns from individual assets. Bulow and Summers pointed out that the annual volatility of the stock market was many times as great as that in gross corporate earnings, suggesting that the riskiness of asset values is the dominant problem investors face. ${ }^{31}$ However, such asset risk reflects variations in the discount rate applied to earnings as well as variations in the earnings themselves. Furthermore, such variations do not imply that the specific assets owned by firms are as risky. For example, an airline that owns its fleet of planes may have a very volatile share price without the depreciated value of the planes themselves varying very much. Hence it is difficult to infer from such market observations the quantitative importance of variations in depreciation of underlying assets. More empirical work is needed on this issue for conclusions to be drawn.

Nonetheless, it is useful to observe how the introduction of economic depreciation risk alters conclusions about effective tax rates; this is done for a range of reasonable parameter values in table 10 . The table shows the values of $\tau$ under the 1982 law for an inflation rate of $\pi=0.06$, an assumed after-tax, risk-free return of $y=0.02$, and a range of values of $\alpha_{\delta}$ from zero to 0.06 . The effective tax rate is calculated for two representative assets, where $\bar{\delta}$ is set equal to the previously used values of $\delta$ in table 3. To make comparisons I set the after-tax return lower to account for the fact that this is now meant to be a risk-free rate, and

31. Jeremy Bulow and Lawrence Summers, "The Taxation of Risky Assets," Working Paper 897 (National Bureau of Economic Research, June 1982). 
assume that nominal depreciation allowances themselves do not vary, so that $z$ is calculated using $y+\pi$ as the discount rate. The range of values for $\alpha_{\delta}$ is meant to provide bounds for movements in $\tau$. An asset for which $\alpha_{\delta}=0.06$ has depreciation so risky that an additional aftertax return of 6 percent is required over the risk-free rate (in addition to the risk premium associated with the variability of gross flows).

Looking at table 10 , one can see that the use of a lower after-tax return in itself has an ambiguous effect on the estimated effective tax rate, raising the effective tax rate for structures and lowering the rate for equipment. As $\alpha_{\delta}$ rises, the effective tax rates diverge for the two classes of assets, with the rate rising for structures and falling for equipment. In general it can be shown that effective tax rates will increase with $\alpha_{\delta}$ unless they are negative, in which case they will become even more negative. This is a general result that applies for any increase in the effective depreciation rate, $\bar{\delta}+\alpha_{\delta}$. Intuitively, one knows that once tax benefits are sufficiently large to provide the investor with a subsidy, this subsidy increases in size relative to the asset's present value of earnings as the lifetime of the asset declines. An increase in capital risk has the effect of shortening an asset's life because it leads the investor to discount future flows more heavily. Thus the expectation that effective tax rates increase with capital risk is valid only if one rules out negative tax rates (which would require a nominal discount rate, $y+\pi$, of at least 11 percent for equipment).

\section{Interest Deductibility and Personal Taxation}

Both interest deductibility and personal taxes have been generally ignored until now in this discussion, and the focus has been on tax issues related to the real rather than the financial side of corporate investment. For many questions, however, these features of the tax on capital income are crucial. One of the reasons why the corporation tax receipts have declined over time has been the increase in nominal interest rates. These rising rates, combined with the deductibility of interest payments and the relative stability of the aggregate corporate debt-equity ratio, led to an increase in interest deductions. Even if this is compensated by an increase in individual tax payments, there are implications for the probability that individual corporations will fail to have taxable income 
and for the viability of the corporate tax as an independent vehicle for raising revenues.

Although the corporate tax is obviously relevant to the choice between corporate and noncorporate investment, the identity of the entity remitting the actual tax payment is of little consequence to the overall incentive to invest in capital. It is important therefore to understand the total tax wedge between the return to corporations before tax and the return to holders of debt and equity after tax, taking account of personal as well as corporate taxes.

Discussions in this area require an understanding of how taxes influence the corporate decision between debt and equity finance. The stability of the aggregate debt-equity ratio at about $1: 3$ requires some explanation, given the apparent tax advantage to debt finance. ${ }^{32}$ Since payments to stockholders in the form of dividends are not tax deductible but interest payments are, there appears to be a strong incentive to finance with debt. Reasons often given for the relatively limited use of debt involve both tax and nontax factors. ${ }^{33}$

Bankruptcy costs are often cited as a reason why corporations do not borrow more. A related argument is that leverage allows a firm to lower the value of its existing long-term debt through investment decisions that make the firm riskier than had been anticipated. This possibility of "cheating" on debt-holders limits the feasible extent of debt finance.

On the tax side, there is a personal tax advantage to equity and a potential corporate tax disadvantage to debt that act to offset debt's apparent tax advantage at the corporate level. For any taxable investor, long-term capital gains receive favorable tax treatment through a 60 percent exclusion and deferral of payment of the tax until the gains are actually realized. The capital gains tax may be the only relevant tax on equity income when marginal equity funds come through retentions. Then the customary approach of weighting dividends and capital gains taxes to derive some overall personal tax rate on equity income has no justification. ${ }^{34}$

32. See Gordon and Malkiel, "Corporation Finance," and Robert Taggart, "Secular Patterns in the Financing of U.S.," in Benjamin Friedman, ed., Corporate Capital Structure in the United States (National Bureau of Economic Research, forthcoming).

33. For a review of these theories see Roger H. Gordon, "Interest Rates, Inflation, and Corporate Financial Policy," BPEA, 2:1982, pp. 461-88.

34. This point is developed in the literature. See Mervyn A. King, "Taxation and the Cost of Capital,"' Review of Economic Studies, vol. 41 (January 1974), pp. 21-35; Alan J. 
When investment is financed through retention of earnings and hence forgone dividends, stockholders postpone paying taxes on dividends and the earnings they represent. When the retentions and the additional earnings they generate are ultimately distributed, the dividends are taxed. In this respect, the dividend tax is like a consumption tax, allowing deductions for saving by the corporation and taxing withdrawals. The after-tax rate of return is unaffected by the level of tax on dividends. Hence the net effect of such taxation is zero on new investment financed by retentions. (There would, of course, be effects induced by changes in the dividend tax rate.) The positive present value of dividend tax receipts results because the capital currently inside the corporation will be taxed upon distribution and because some equity funds will come from the sale of new shares, for which there is no corresponding personal tax saving.

Even with the relatively small capital gains tax serving as the only effective individual tax on equity income, it remains difficult to argue that very many investors would have a tax preference for equity financing, given that the maximum personal tax rate on interest income is 50 percent, only 4 points higher than the statutory corporate rate at which interest payments are deducted. Moreover, evidence from bond markets suggests that individuals in tax brackets substantially below the top marginal rate can limit their tax liability by holding tax-exempt municipal debt. ${ }^{35}$ Hence the potential individual tax gain from holding equity versus debt would appear to be substantially below the corporate tax rate.

Even if increased leverage does not lead to a serious threat of bankruptcy, however, it increases the probability that the full value of interest deductions themselves will not be received. Hence borrowing to take advantage of tax deductibility will tend to be self-limiting. A recent study using actual corporate tax returns for 1978 estimated that under the 1983 tax law the average marginal tax rate at which interest

Auerbach, "Share Valuation and Corporate Equity Policy," Journal of Public Economics, vol. 11 (June 1979), pp. 291-305; and David F. Bradford, "The Incidence and Allocation Effects of a Tax on Corporate Distributions," Journal of Public Economics, vol. 15 (April 1981), pp. 1-22. For a detailed discussion of its implications, see Alan J. Auerbach, "Taxation, Corporate Financial Policy and the Cost of Capital," Journal of Economic Literature, vol. 21 (September 1983), pp. 905-40.

35. Joseph J. Cordes and Steven M. Sheffrin, "Estimating the Tax Advantage of Corporate Debt," Journal of Finance, vol. 38 (March 1983), pp. 95-105. 
payments would be deductible is 0.31 percent, not allowing for the possibility of carrying back these deductions or the expected value from carrying them forward. ${ }^{36}$ However, this may overstate the calculations based on the transition probabilities in table 7 . They suggest that, with a nominal discount rate of 10 percent, a typical firm will receive about 92 cents per dollar of interest deductions, in present value, equivalent to immediate deduction at a rate of over 42 percent. Thus, assuming an individual tax rate on debt of below 30 percent, there remains an advantage to debt that can only be explained by nontax factors such as those mentioned above.

An implication of this result is that firms or individual assets for which nontax borrowing costs are small are likely to face a relatively low overall effective tax rate. It has often been supposed that this is the case for structures, as compared to equipment ${ }^{37}$ This would be an important offset to the apparent bias against structures imposed by the corporate tax. However, while highly leveraged purchases of apartment buildings and shopping centers by doctors and other professionals may be common, there has yet to be any convincing empirical evidence suggesting this is an important effect for corporate level investment. ${ }^{38}$ Thus there is no evidence that the results derived above concerning differential taxation of assets would be qualitatively affected by the incorporation of interest deductibility and personal taxes in the calculations.

\section{Inflation and the Effective Tax Rate}

The primary reason why effective corporate tax rates did not fall appreciably during the 1970 s was that inflation increased steadily over

36. Gordon and Malkiel, "Corporation Finance," estimate that, before the tax reduction of 1981, the marginal tax rate implicit in municipal debt was between 20 percent and 30 percent.

37. This viewpoint is stated, for example, in Robert E. Hall, "Tax Treatment of Depreciation, Capital Gains, and Interest in an Inflationary Economy," in Hulten, ed., Depreciation, Inflation, and the Taxation of Income from Capital, pp. 149-66.

38. I found no evidence using firm panel data (which included information on asset composition) that structures were financed more heavily with debt than equipment. I did find, however, that the presence of a tax loss carry-forward exerted a negative impact on leverage, as would be expected. See Alan J. Auerbach, "Real Determinants of Corporate Leverage," in B. Friedman, ed., Corporate Capital Structure in the United States (National Bureau of Economic Research, forthcoming). 
the period. This decreased the real value of depreciation allowances received and led to the taxation of nominal inventory profits. For capital purchased by corporations, however, the overall incentive to invest is affected by inflation in three additional ways: through the increase in inflation premiums on debt that are tax deductible, through the increased individual taxation of such premiums, and through the taxation of capital gains of shareholders that are purely nominal in character. The aggregate impact of inflation on the effective tax on capital has been the subject of several studies. Two of the major studies reached quite different conclusions about the sensitivity to inflation of the tax wedge on corporate source income.

Feldstein and Summers estimated the total tax wedge by combining a weighted average of estimated marginal tax rates of holders of corporate securities with average tax rates at the corporate level, and found the total tax rate to be very sensitive to inflation. ${ }^{39}$ For example, they estimated that in 1970 there was a total effective tax rate on corporate source income of 76.8 percent at an inflation rate of 5.5 percent, with 26.6 percent of the taxes collected due to inflation. This translates into an increase of 3.3 percentage points in the total effective tax rate per percentage point increase in the inflation rate.

Using a cost-of-capital methodology such as the one used in this paper to account for both corporate and individual taxes, King and Fullerton found both a lower tax wedge and a much smaller sensitivity to the inflation rate ${ }^{40}$ Under the same 1970 tax law, they estimated that a rise in the inflation rate from zero to $6 \frac{2}{3}$ percent would have raised the estimated effective tax rate by 3.5 percentage points, from 43.7 to 47.2 percent, or 0.5 percentage point per percentage point increase in the inflation rate.

The major reason for the difference in the conclusions of these two studies appears to be differing assumptions about the marginal tax rate for individuals and the marginal tax rate faced by financial intermediaries. Estimates of the impact of inflation are particularly sensitive to assumptions about the marginal tax rate faced by recipients of corporate interest payments. An expression analogous to equation 4 can be derived for the total effective tax rate, $\tau_{T}$, accounting for interest deductibility and all

39. Feldstein and Summers, "Inflation and the Taxation of Capital Income in the Corporate Sector."

40. King and Fullerton, eds., The Taxation of Income from Capital. 
Table 11. The Sensitivity of Effective Overall Tax Rates to Interest Deductibility and Inflation ${ }^{a}$

Percent

\begin{tabular}{|c|c|c|c|c|c|c|c|c|}
\hline \multirow[b]{2}{*}{$\begin{array}{l}\text { Inflation } \\
\text { rate }\end{array}$} & \multicolumn{4}{|c|}{ General industrial equipment } & \multicolumn{4}{|c|}{ Industrial structures } \\
\hline & Base & Low & $\begin{array}{c}\text { Inter- } \\
\text { mediate }\end{array}$ & High & Base & Low & $\begin{array}{c}\text { Inter- } \\
\text { mediate }\end{array}$ & High \\
\hline No inflation & -47.6 & -70.9 & -54.0 & -45.5 & 25.3 & 13.5 & 22.1 & 26.4 \\
\hline 4 percent & -11.4 & -46.5 & -21.1 & -7.5 & 36.3 & 16.2 & 30.7 & 38.5 \\
\hline 8 percent & 8.2 & -35.3 & -3.8 & 13.2 & 42.3 & 15.0 & 34.7 & 45.5 \\
\hline
\end{tabular}

Source: Author's calculations as described in the text.

a. Low estimates assume $b=0.5$ and $\theta=0.2$; intermediate estimates, $b=0.25$ and $\theta=0.2$; high estimates, $\mathrm{b}=0.25$ and $\theta=0.4$.

taxes paid by the holders of corporate securities. The expression is the same as equation 4 except that $r$ in the second term is replaced by the net return to investors after all taxes, $n$, and this accounts for the fact that $r$ itself depends on personal income tax rates and corporate interest deductibility.

$$
\tau_{T}=\frac{(r+\delta)(1-k-u z)-(n+\delta)(1-u)}{(r+\delta)(1-k-u z)-\delta(1-u)} .
$$

If investors receive a real net return of $n$ on both equity and debt and marginal equity finance is through retentions, it is easy to show that ${ }^{41}$

$$
r=n\left[b \frac{1-u}{1-\theta}+(1-b) \frac{1}{1-\gamma}\right]+\pi\left[b \frac{\theta-u}{1-\theta}+(1-b) \frac{\gamma}{1-\gamma}\right]
$$

where $\gamma$ is the accrual equivalent tax on capital gains and $\theta$ is the personal tax on interest income.

In addition to the effect on $r$, inflation also affects the present value of the depreciation allowances, $z$. Using 8 and 9 , one can estimate the marginal impact of inflation on $\tau_{T}$ for different assets and tax parameters. This is done in table 11 for the two representative assets, industrial equipment and structures, under the current tax system. In all calculations I set $r=0.04, \gamma=0.05$, and $u=0.46$, and estimated effective tax rates at different inflation rates under different assumptions about the parameters $\theta$ and $b$. For the sake of comparison, calculations based on the earlier assumptions that $\theta=b=\gamma=$ zero are presented in the

41. See Auerbach, "Inflation and the Tax Treatment of Firm Behavior." 
"base" column. Since $r$ is taken as given in the calculations, the net return to investors, $n$, varies with the rate of inflation.

As can be seen in table 11, the introduction of interest deductibility and personal taxes has the effect of lowering the overall effective tax rate on both equipment and structures for the low and intermediate cases. These are the cases in which the net impact of the additional tax features makes the net return $n$ exceed $r$. It is in these same cases that an increase in inflation raises $n$, given $r$, as the initial effect is simply magnified by the increases in the nominal interest rate. This reduces the sensitivity of the overall tax rate to inflation. For the intermediate case in which the debt-assets ratio is set at 0.25 and the personal tax rate at 0.2 , the effective tax rate on equipment rises from -54.0 percent to -3.8 percent, while that on structures rises from 22.1 percent to 34.7 percent as inflation increases from zero to 8 percent. The general result that the tax rates faced by short-lived assets are more sensitive to inflation has been documented previously ${ }^{42}$ Raising the assumed personal tax rate on interest income from 0.2 to 0.4 , in line with Feldstein and Summers, makes both tax rates rise more rapidly. On the other hand, setting $b=0.5$ instead of 0.25 essentially removes the effect of inflation on the tax rate for structures. Since it has been argued that observed debt-asset ratios may understate marginal leverage, this may be a reasonable assumption to make..$^{43}$ Hence it appears difficult to measure with great confidence the impact that inflation has on the effective tax rates facing fixed investment.

\section{Asset Valuation and Deferred Taxes}

Just as aggregate revenues from the corporate tax are often cited as evidence of the tax's overall impact, it is customary to measure the magnitude of tax incentives for investment by the associated loss in annual tax receipts. The error involved in doing so can be quite severe.

For example, suppose there was a change in the timing of depreciation allowances that accelerated their rate of receipt but compensated for

42. See Alan J. Auerbach, "Inflation and the Choice of Asset Life," Journal of Political Economy, vol. 87 (June 1979), pp. 621-38.

43. See Joseph E. Stiglitz, "Taxation, Corporate Financial Policy and the Cost of Capital," Journal of Public Economics, vol. 2 (February 1973), pp. 1-34. 
this with a lower base on which the allowances were calculated so that the net impact on the present value of these depreciation allowances is nil. There would be no impact on the incentive to invest, nor would there be any obvious reason why the shortfall in government revenue caused by the earlier deduction of depreciation allowances would have an effect on saving: owners of assets receiving these "tax cuts" would have to repay them in the future, with interest. By assumption, the government has not given them a net increase in resources.

This argument might seem to carry over directly to the case of all taxes: if the government, in the long run, repays its debt, lower taxes today must be compensated for by higher ones in the future. A significant difference between taxes in general and taxes on capital assets is that future taxes on capital assets are immediately capitalized. One does not have to believe in Barro's altruistic families to conclude that a pure change in the timing of such tax payments will be neutral ${ }^{44}$ It is not even necessary that the owners of such assets look beyond the present. This neutrality is the result of simple arbitrage. Assets that already have received a tax benefit but now are liable for future "deferred taxes" are less attractive to the owner than comparable new assets that have yet to receive the initial benefits.

Consider, for example, a five-year-old piece of equipment under current law that has no remaining depreciation deductions or investment tax credits. For it, the value of $k+u z$, in the terminology used above, is zero. The cash flows that it generates in the future will be fully taxable. A comparable new asset is more attractive (after adjustment for differences in real productivity), because for it the value of $k+u z$ is not zero. Hence its value will be higher, by the ratio $1 /(1-k-u z)$.

A related reason why old assets should carry a discount is the general practice of introducing investment incentives that apply only to new assets. The motivation for this practice is that increases in investment tax credit or acceleration of depreciation allowances provides more "bang for the buck" in terms of reductions in the cost of capital per dollar of revenue lost. This is not surprising, given that such incentives do not lower the effective tax rate on existing capital goods, while broader changes such as corporate rate reductions do. The gap between the taxation of old and new assets caused by such investment incentives

44. Robert J. Barro, "Are Government Bonds Net Wealth?' Journal of Political Economy, vol. 82 (November-December 1974), pp. 1095-1117. 
leads to a further discount in the value of old assets relative to new ones. ${ }^{45} \mathrm{~A}$ corollary is that when there is inflation, old assets will be discounted because their depreciation allowances are based on a lower price index than those of new assets. ${ }^{46}$

When older assets face higher effective tax rates than new ones, the resulting discount in their value may be considered to be caused by an implicit obligation to the government to pay taxes in excess of those due on comparable new assets. The difference in market value of the old and new assets should reflect the present value of the obligation. In particular, the owner of such an asset could offset this difference in future obligations by committing the difference in the value of the two assets to government debt and using the interest payments to cover the extra taxes due in the future. Hence the current tax system is equivalent to a tax that imposes the same effective rate on old and new assets, combined with a liability of owners of old assets to the government equal to the total tax-induced discount on old assets under the current system.

Recognizing this point is important because tax revenues in a given year can change for many reasons: a change in the corporate tax burden in general, a change in the relative tax burdens on old and new assets, or a change in the timing of the collections. These have very different substitution effects through the cost of capital and very different income effects through changes in the value of existing assets. It is impossible to draw any general conclusion from a drop in current corporate revenues about whether the incentive for corporations to invest has increased or whether potential crowding out has been increased through a rise in private wealth.

For example, an upward movement in the statutory corporate tax rate, combined with a further acceleration of depreciation allowances aimed at maintaining the same incentive to invest in new capital, would increase the present value of corporate tax receipts by what is essentially

45. This presumes that old assets are not sold to take advantage of the new provisions. Even ignoring transaction costs, such behavior would only yield a net reduction in taxes for a small fraction of the capital stock, because of the tax treatment of the sale and the limited availability of the investment tax credit for used assets. See Auerbach, "Inflation and the Tax Treatment of Firm Behavior," and Alan J. Auerbach and Laurence Kotlikoff, "Investment versus Savings Incentives: The Size of the Bang for the Buck and the Potential for Self-Financing Business Tax Cuts," in L. H. Meyer, ed., The Economic Consequences of Government Deficits (Kluwer-Nijhoff, 1983), pp. 121-49.

46. See Auerbach, "Inflation and the Choice of Asset Life." 
a lump-sum tax on existing capital. This may be thought of as forcing the owners of such capital to assume an additional debt to the government. The real effects of such a policy would be equivalent to that of a onetime lump-sum tax used to retire government debt, a scheme without direct substitution effects. Yet, as measured, this policy would quite possibly appear to increase the current deficit, due to the acceleration of depreciation allowances on new capital. ${ }^{47}$ It would clearly be desirable to have annual corporate revenues after adjustment include changes in the value of the deferred tax liability of asset holders to the government. Assuming that markets capitalize future taxes, such an adjustment is equivalent to an estimate of the size of the discount on existing capital due to the tax system.

To estimate the relation between the value of an existing unit of capital and its replacement cost, note that at any time the value of the after-tax flows from a new unit of capital equals its purchase price. Normalizing this price to 1 yields

$$
1=(1-u) F+k+u z,
$$

where $F$ is the present value of the asset's before-tax flows, and $u, k$, and $z$ are as defined in equation 1. For an existing capital good of age $t$, which under the assumption of geometric decay is equivalent in terms of productivity to $(1-\delta)^{t}$ units of new capital, the value is

$$
v^{t}=(1-u) F(1-\delta)^{t}+u z^{t},
$$

where $z^{t}$ is the present value of depreciation allowances that remain for the asset. The ratio of market value to replacement cost of such an asset, its $q$ value, is

$$
q^{t}=\frac{v^{t}}{(1-\delta)^{t}}=(1-k-u z)+\frac{u z^{t}}{(1-\delta)^{t}} .
$$

This differs from Tobin's $q$ by the assumption that, except for tax effects,

47. An example of this problem of confusing changes in timing and changes in the tax burden came in the discussion of my proposal with Dale Jorgenson to give investors the discounted value of economic depreciation allowances in the year of an asset's purchase. See Alan J. Auerbach and Dale W. Jorgenson, "Inflation-Proof Depreciation of Assets," Harvard Business Review, vol. 58 (September-October 1980), pp. 113-18. Although our original proposal would not have lowered effective tax rates on capital in the aggregate, some viewed it as infeasible because of the large "deficits" it would have produced in the initial years of its application. 
old capital is valued at its replacement cost. This value equals 1 when $z^{t}$ $=(1-\delta)^{t}(k+u z)$ : assets receive tax benefits proportional to their productivity or physical value. This would be true under a tax on economic income, for then $k+u z$ would equal $\delta /(r+\delta)$ and $z^{t}$ would equal $[\delta /(r+\delta)](1-\delta)^{t}$. Generally, however, $q^{t}$ is below 1 . Even without the intentional acceleration of depreciation allowances, inflation causes the present value of old allowances based on original asset purchase prices to fall well short of the value of allowances new assets receive.

Using equation 12 , I estimated the values for $q^{t}$ for all vintages of each of the thirty-four asset classes from 1953 to 1982, ignoring tax law changes before 1953. These vintage-specific values of $q$ were aggregated into the annual asset-specific average of $q$ under the assumption that each net asset stock grew over the period at a growth rate of 4 percent. ${ }^{48}$ With the use of capital stock weights described in appendix A, these were aggregated to form a single series for the overall value of average $q$, shown in the first column of table 12 . The series is characterized by a downward trend. In the 1950s the average $q$ values actually exceeded unity for some assets. With the investment tax credit, accelerated depreciation, and inflation, these values fell. Large reductions occurred with the tax changes of 1962, 1972, and 1981. The corporate rate reductions in the mid-1960s and late 1970s had no observable impact, since they applied uniformly to old and new capital. Note also that $q$ increased in years when the treatment of new capital goods was made less favorable, as occurred with the removal of the investment tax credit in 1967 and again in 1970.

As suggested above, this divergence of average $q$ from 1 is essentially a deferred tax liability of holders of existing assets. The second column of table 12 shows the adjustments to annual revenue that would be made if such debt were explicitly accounted for. The numbers equal each year's change in the value of the implicit debt, ${ }^{49}$ less real after-tax interest payments on the stock of such debt, based on a return of 2 percent. By

48. This is the annual growth rate of the net corporate stock of fixed nonresidential capital from 1952 to 1981, based on numbers presented in John C. Musgrave, "Fixed Capital Stock in the United States: Revised Estimates," Survey of Current Business, vol. 61 (February 1981), pp. 57-68; and Musgrave, "Fixed Reproducible Tangible Wealth in the United States."

49. The value of the implicit debt for each year equals $(1-q)$ multiplied by the aggregate net stock of fixed corporate capital, taken from Musgrave, "Fixed Capital Stock in the United States: Revised Estimates" and "Fixed Reproducible Tangible Wealth in the United States." 
Table 12. Average Values of $q$ Implied by the Corporate Tax Law, 1953-82

\begin{tabular}{|c|c|c|}
\hline Year & $\begin{array}{l}\text { Average } \\
q(\text { ratio })\end{array}$ & $\begin{array}{c}\text { Implied revenue } \\
\text { adjustment } \\
\text { (billions of } \\
1972 \text { dollars) }\end{array}$ \\
\hline 1953 & 0.921 & $\ldots$ \\
\hline 1954 & 0.898 & 7.6 \\
\hline 1955 & 0.908 & -2.6 \\
\hline 1956 & 0.924 & -4.7 \\
\hline 1957 & 0.935 & -3.4 \\
\hline 1958 & 0.940 & -1.9 \\
\hline 1959 & 0.940 & 0.1 \\
\hline 1960 & 0.946 & -2.1 \\
\hline 1961 & 0.945 & 0.5 \\
\hline 1962 & 0.894 & 21.0 \\
\hline 1963 & 0.900 & -2.0 \\
\hline 1964 & 0.893 & 4.0 \\
\hline 1965 & 0.898 & -0.4 \\
\hline 1966 & 0.899 & 1.9 \\
\hline 1967 & 0.927 & -12.9 \\
\hline 1968 & 0.889 & 22.6 \\
\hline 1969 & 0.890 & 1.8 \\
\hline 1970 & 0.928 & -21.8 \\
\hline 1971 & 0.926 & 1.9 \\
\hline 1972 & 0.867 & 40.1 \\
\hline 1973 & 0.864 & 5.1 \\
\hline 1974 & 0.865 & 1.9 \\
\hline 1975 & 0.867 & -1.2 \\
\hline 1976 & 0.845 & 17.3 \\
\hline 1977 & 0.834 & 10.2 \\
\hline 1978 & 0.835 & 1.6 \\
\hline 1979 & 0.838 & 0.7 \\
\hline 1980 & 0.838 & 2.6 \\
\hline 1981 & 0.781 & 60.8 \\
\hline 1982 & 0.792 & n.a. \\
\hline
\end{tabular}

Source: Author's calculations as described in the text.

n.a. Not available.

this measure, corporate tax revenues were really 134.6 billion (current) dollars higher than the amount reported in 1981 because of the substantial increase in the implicit debt held by owners of existing capital.

\section{The Future of the Corporate Tax}

As a fraction of GNP, the corporate tax now raises less than a third of what it did three decades ago. While effective marginal tax rates on 
investment have declined accordingly, the distortions of the corporate tax structure have not. The calculations in table 6 suggest a steadily worsening allocation of fixed capital within the U.S. corporate sector.

Many other problems remain, too. The use of accelerated depreciation and the investment tax credit to reduce effective tax rates have made the problem of tax losses more acute. Any resemblance between economic income and taxable income that existed thirty years ago has vanished, and many profitable companies, particularly those that are growing, cannot use all their tax benefits. Though effective tax rates are lower than they were in the 1970s, they still are sensitive to the inflation rate because of the use of nominal magnitudes in calculating the tax base. Finally, the choice between debt and equity finance remains distorted by the presence of two levels of taxation of corporate source income.

Given the low level of corporate revenues at present, abolition of the corporate tax has its appeal. Such a move would certainly alleviate some of the problems described above. At the same time, however, it would be a singularly ineffective way of stimulating investment because it would reduce average tax rates much more than marginal tax rates.

As shown in table 4, the effective corporate tax rate on new, equityfinanced fixed capital is now below 25 percent. Removal of the corporate tax would bring this rate to zero but would also eliminate the substantial benefit of interest deductibility. Thus it would probably result in a very small net reduction in taxation for new investments. At the same time, repeal of the corporate tax would forgive the implicit debt owed the government in deferred taxes, currently in excess of 20 percent of the fixed corporate capital stock. Given the capital stock's 1981 replacement cost of $\$ 2.05$ trillion, this amounts to a transfer of $\$ 427$ billion. ${ }^{50}$

The continued interest in the consumption tax as an alternative to the individual income tax and, indeed, the recent moves toward such a tax through the sheltering of individual capital income also provide an argument for removing the corporate tax, for capital income would not be taxed under a consumption tax. An alternative scheme that would have the same marginal impact without the windfalls is a cash-flow tax, discussed in detail by the Meade Committee in the United Kingdom as a companion for a personal consumption tax.${ }^{51}$ Like a consumption tax,

50. See Musgrave, "Fixed Reproducible Tangible Wealth in the United States."

51. Institute for Fiscal Studies, The Structure and Reform of Direct Taxation (London: Allen and Unwin, 1978). 
it would amount to a tax on the difference between initial assets plus income and final assets in each tax period, in this case at the corporate level. The most straightforward method of accomplishing this would be through the immediate expensing of gross investment (real plus financial) in conjunction with the continued taxation of gross income, before depreciation. The chief drawback of the cash-flow tax, however, is that it does not solve the problem of tax losses in the way that repeal of the corporate tax would. Otherwise, the two alternatives differ primarily in the size of the wealth transfer to owners of corporations.

If the corporate tax is not to be repealed outright, the problem of tax losses must be addressed. Straightforward economic solutions exist: unlimited carrying forward with interest, for example, would maintain protection against fraudulent loss claims while at the same time preserving the value of tax deductions for viable enterprises. But one should take warning from the recent legislative fiasco involving safe-harbor leasing. This is an area of tax policy in which common perceptions seem particularly resistant to economic evidence.

APPENDIX A

\section{Methodology and 1954-82 Changes in Tax Code}

This APPENDIx presents the methodology used to calculate effective tax rates in the text.

The first step in these calculations is to estimate each asset's effective tax rate according to equation 4 . As already stated, it is assumed that investors all used accelerated methods where available. Investments are assumed to take place midway through the year, with the investment credit and (before 1981) half the first full year's depreciation allowances received immediately. Marginal products and remaining depreciation allowances are assumed to come at subsequent one-year intervals.

The major changes in the tax code taken into account are as follows.

1954 Introduction of accelerated methods; all assets are assumed to use double-declining balance with a switch-over to straight- 
line methodology, instead of the straight-line previously assumed.

1962 Introduction of a 7 percent investment tax credit (with fullbasis adjustment) and of shortened "guideline" lifetimes by the U.S. Department of the Treasury, instead of Bulletin F lifetimes previously assumed.

1964 Repeal of basis adjustment for investment tax credit. A cut in corporate tax rate from 52 percent to 50 percent.

1965 A cut in corporate tax rate from 50 percent to 48 percent.

1967 Suspension of investment tax credit.

1968 Introduction of 10 percent surcharge on income tax.

1969 Reinstatement of investment tax credit.

1970 Removal of investment tax credit, reduction of surcharge, reduction of structures write-off to 150 percent declining balance, with switch-over to straight-line methodology.

1971 Removal of surcharge.

1972 Shortening of asset lives through the asset depreciation range system; reintroduction of investment tax credit.

1975 Increase of investment tax credit to 10 percent.

1979 Reduction in corporate tax rate from 48 percent to 46 percent.

1981 Economic Recovery Tax Act, as described in the text.

1982 Tax Equity and Fiscal Responsibility Act, as described in text.

The years listed are the first for which the changes are included. Except for the 1982 act, any change was counted in the year enacted if it was effective before July 1 of that year. Otherwise, it was deferred to the following year. The 1982 act became effective after July 1, but is included for 1982 to allow an analysis of its effects.

Special tax rules apply to public utility structures and oil-drilling equipment. The latter category is problematic because there are various depletion and write-off provisions that are difficult to capture in the current framework. The calculations here follow the assumptions used in King and Fullerton. ${ }^{52}$

To convert these asset-specific rates into industry rates, the capital stock matrix also used by King and Fullerton was adopted. This $44 \times$ 34 matrix has entries equal to the estimates for 1977 of the net stock of

52. King and Fullerton, eds., The Taxation of Income from Capital. 
each type of the thirty-four assets present in each of the forty-four industries. This matrix is converted to a corporate version using estimates for each industry of the fractions of equipment and structures in the industry that are held by corporations. The capital stocks themselves were derived by Fraumeni and Jorgenson, using data on capital flows and annual levels of industry-by-industry investment. ${ }^{53}$ Further details are provided by King and Fullerton.

APPENDIX B

\section{Measuring the Deadweight Loss from Differential Corporate Taxation}

Assuming that value added in industry $i$ can be represented by the CobbDouglas production function, one obtains

$$
Y_{i}=a_{i} \pi K_{j i}^{\alpha_{j i}} X_{i}^{1-\beta_{i}} \quad \beta_{i}=\sum_{j} \alpha_{j i},
$$

where $K_{j i}$ is the capital stock of category $j$ used in industry $i$ and $X_{i}$ is labor used in industry $i$. With no loss of generality, one can define capital stock units so that the relative price of each capital good, $q_{j}$, equals 1 .

Consider first the case in which capital is allocated according to the actual costs of capital imposed by the market. By the normalization that $q_{j}=1$, the cost of capital type $i$ is

$$
c_{j}=\frac{r}{1-\tau_{j}}+\delta_{j}=\rho_{j}+\delta_{j},
$$

where $\tau_{j}$ is the effective tax rate, $r$ is the real after-tax return (assumed to be 4 percent), and $\delta_{j}$ is the asset's depreciation rate. One may think of corporate sector allocation as being made by a single, competitive firm seeking to maximize profits, where profit equals gross output (including depreciation) less the cost of capital, subject to the constraint that the

53. See Barbara M. Fraumeni and Dale W. Jorgenson, "Capital Formation and U.S. Productivity Growth, 1948-1976," in Ali Dogramaci, ed., Productivity Analysis: A Range of Perspectives (Martinus Nijhoff Publishing, 1981), pp. 49-70. 
vector of actual outputs, $\bar{Y}=\left(\bar{Y}_{1}, \ldots\right)$, be produced and the economy's actual stock of labor, $\bar{X}$, be used. This yields a Lagrangian expression for the actual capital stock, $K^{a}$,

$$
\begin{aligned}
K^{a}= & \max \sum_{i}\left(a_{i} \underset{j}{\pi} K_{j i}^{\alpha_{j i}} X_{i}^{1-\beta_{i}}+\sum_{j} \delta_{j} K_{j i}-\sum_{j} c_{j} K_{j i}\right) \\
& -\sum_{i} \theta_{i}\left(a_{i} \underset{j}{\pi} K_{j i}^{\alpha_{j i}} X_{i}^{1-\beta_{i}}-\bar{Y}_{i}\right)+\phi\left(\sum_{i} X_{i}-\bar{X}\right) .
\end{aligned}
$$

The first-order conditions from 15 may be combined to yield

$$
K^{a}=\sum_{i}\left(\frac{\phi^{\left(1-\beta_{i}\right)} \tilde{\rho}_{i}^{\beta_{i}} \bar{Y}_{i}}{v_{i}} \cdot \sum_{j} \frac{\alpha_{j}}{r_{j}}\right),
$$

where

$$
\begin{aligned}
& \sum_{i}\left(\frac{\phi^{-\beta_{i}}\left(1-\beta_{i}\right) \tilde{\rho}^{\beta_{i}} \bar{Y}_{i}}{\nu_{i}}\right)=X, \\
& \nu_{i}=a_{i} \prod_{j} \alpha_{j i}^{\alpha_{j i}}\left(1-\beta_{i}\right)^{\left(1-\beta_{i}\right)},
\end{aligned}
$$

and

$$
\tilde{\rho}_{i}=\underset{j j}{\pi \rho_{j i} / \beta_{i}}
$$

is the weighted geometric mean of the required, before-tax rates of return in industry $i$.

Equations 16 and 17 can be simplified. Note that, under competitive conditions, the total supply of labor, $\bar{X}$, satisfies

$$
\bar{X}=\frac{1}{w} \sum_{i}\left(1-\beta_{i}\right) \bar{Y}_{i}
$$

(where $w$ is the competitive wage), and the technological term, $v_{i}$, also equals

$$
v_{i}=\tilde{\rho}_{i}^{\beta_{i}} w^{1-\beta_{i}} .
$$

One may choose the units of labor so that $w=1$, with no loss of generality, and use equations 20 and 21 to reexpress 16 and 17:

$$
K^{a}=\sum_{i} \phi^{\left(1-\beta_{i}\right)} \bar{Y}_{i} \cdot \sum_{j} \alpha_{j} / \rho_{j},
$$


where

$$
\sum_{i}\left(\phi^{-\beta_{i}}-1\right)\left(1-\beta_{i}\right) \bar{Y}_{i}=0
$$

The solution to 23 is $\phi=1$. This is not surprising because $\phi$ is the shadow price of labor (see 15), that is, the market wage.

The minimum capital stock necessary to produce $\bar{Y}$, holding $\bar{X}$ fixed, is found by solving the Lagrangian,

$$
K^{*}=\min \sum_{i} \sum_{j} K_{j i}-\sum_{i} \lambda_{i}\left(a_{i} \pi_{i} K_{j i}^{\alpha_{j i}} X_{i}^{1-\beta_{i}}-\bar{Y}_{i}\right)+\gamma\left(\sum_{i} X_{i}-\bar{X}\right) .
$$

Using the same solution technique as before, one obtains

$$
K^{*}=\sum_{i}\left(\frac{\gamma^{\left(1-\beta_{i}\right)} \beta_{i} Y_{i}}{v_{i}}\right)
$$

where

$$
\sum_{i}\left(\frac{\gamma^{-\beta_{i}}\left(1-\beta_{i}\right) \bar{Y}_{i}}{v_{i}}\right)=\bar{X}
$$

Again using 20 and 21,25 and 26 can be rewritten as

$$
K^{*}=\sum_{i} \gamma^{\left(1-\beta_{i}\right)} \tilde{\rho}_{i}^{-\beta_{i}} \beta_{i} \bar{Y}_{i}
$$

where

$$
\sum_{i}\left[\left(\gamma \tilde{\rho}_{i}\right)^{-\beta_{i}}-1\right]\left(1-\beta_{i}\right) \bar{Y}_{i}=0
$$

The term $\gamma$ may be thought of as the inverse of the weighted-average aggregate cost of capital. If $\tilde{\rho}_{i}$ were constant across $i$, it would equal $1 / \gamma$. For purposes of exposition, we define $\bar{\rho}=1 / \gamma$. Subtracting the expression for $K^{*}$ from that for $K^{a}$ yields an expression for the "wasted" capital stock,

$$
\Delta K=\sum_{i} Q_{i} \sum_{j}\left(\frac{\alpha_{j i}}{\beta_{i}}\right)\left(\frac{\tilde{\rho}_{i}}{\rho_{j}}-1\right)+\sum Q_{i}\left[1-\left(\frac{\tilde{\rho}_{i}}{\bar{\rho}}\right)^{\left(1-\beta_{i}\right)}\right],
$$

where

$$
Q_{i}=\bar{Y}_{i} \beta_{i} \tilde{\rho}_{i}^{-1}
$$

It may be shown that the first sum on the right-hand side of 29 achieves a minimum of zero when $\tilde{\rho}_{i}=\rho_{j} \forall_{i, j}$, and that the second term achieves 
a minimum of zero when $\tilde{\rho}_{i}$ is constant over $i$ and (by 28) equal to $\bar{\rho}$. Hence it is natural to interpret these terms as the wastage due to variation in effective tax rates within industries, and between them, respectively. Dividing equation 29 by equation 22 gives an estimate of the fraction of the capital stock that is wasted,

$$
L=\frac{\Delta K}{K}=\frac{\sum_{i} Q_{i} \sum_{j}\left(\frac{\alpha_{j i}}{\beta_{i}}\right)\left(\frac{\tilde{\rho}_{i}}{\rho_{j}}-1\right)+\sum_{i} Q_{i}\left[1-\left(\frac{\tilde{\rho}_{i}}{\bar{\rho}}\right)^{\left(1-\beta_{i}\right)}\right]}{\sum_{i} Q_{i} \sum_{j}\left(\frac{\alpha_{j i}}{\beta_{i}}\right)\left(\frac{\tilde{\rho}_{i}}{\rho_{j}}\right)} .
$$

To solve 31 , I set $\beta_{i}$ equal to the share of capital in value added in industry $i$ taken from the 1972 Census of Manufactures, $\bar{Y}_{i}$ equal to that value added, and use the 1977 capital stock weights described in appendix A for $\left(\alpha_{j i} / \beta_{i}\right)$. Because three of the forty-four industries (numbers 38, 39, and 40 ) are combined in the Census (which has forty-two industry categories), I combine these three industries' capital stocks in doing the calculations. The terms $\rho_{j}$ come from each year's estimated effective tax rates by asset category.

\section{APPENDIX C}

\section{Estimating the Effective Tax Rate on Risky Assets}

ThE ANALYsis in this section uses the methodology presented in Alan J. Auerbach, "Evaluating the Taxation of Risky Assets," Working Paper 806 (National Bureau of Economic Research, November 1981).

Suppose capital of a certain type is homogeneous and depreciates each year at some stochastic rate, $\delta$, yielding a risky cash flow, $f$, per unit of capital. Assume for simplicity that $\delta$ and $f$ are jointly independently and identically distributed over time with means $\bar{\delta}$ and $\bar{f}$, respectively.

Let $i$ be the discount rate that, when applied to the mean $\bar{f}$, yields the risk-adjusted present value of $\tilde{f}$. Define $x$ similarly for $\delta$, and let $y$ denote the risk-free rate. Note that because depreciation represents a negative contribution to the firm's overall return, the riskiness of $\delta$ would normally lead to a risk-adjusted discount rate, $x$, that is below the risk-free rate, $y$. (Indeed, $x$ may be considerably less than zero.) This corresponds to 
the normal result of risk reducing the value of the future expected return, in this case by magnifying $\delta$.

A simplification is made for convenience of notation. Observe that any system of depreciation allowances and investment tax credits has the same value to the investor ex ante as a scheme that allows fractional economic depreciation at rate $\psi$. With this simplification, and because of the stationarity and independence of $\tilde{f}$ and $\tilde{\delta}$ over time, one may consider the firm as facing a series of identical one-period decisions. The condition for equilibrium is that the risk-adjusted one-period holding yield equals the interest rate, or

$$
\frac{\bar{f}(1-u)}{1+i}-\frac{\bar{\delta}}{1+x}+\frac{u \psi \bar{\delta}}{1+x}=\frac{y}{1+y},
$$

where, as before, $u$ is the statutory tax rate.

To solve for $\psi$, one must know the present value of economic depreciation. The value of this period's depreciation is $\bar{\delta} /(1+x)$. The next period's value is the value seen from the next period per dollar of capital, also $\bar{\delta} /(1+x)$, multiplied by the present value of capital at the beginning of next period, $[1 /(1+r)]-[\bar{\delta} /(1+x)]$. Continuing in this way, one can obtain the present value of economic depreciation,

$$
\begin{aligned}
z_{E}= & \frac{\bar{\delta}}{1+x}+\left(\frac{1}{1+y}-\frac{\bar{\delta}}{1+x}\right) \frac{\bar{\delta}}{1+x} \\
& +\cdots\left[\left(\frac{1}{1+y}-\frac{\bar{\delta}}{1+x}\right)^{t} \frac{\bar{\delta}}{1+x}\right] \\
& +\cdots=\frac{\bar{\delta}}{\bar{\delta}+y\left(\frac{1+x}{1+y}\right)} .
\end{aligned}
$$

Thus if actual depreciation allowances provide value $z$, and there is an investment tax credit at rate $k$, one obtains

$$
\psi=\frac{k+u z}{u \bar{\delta}}\left[\bar{\delta}+y\left(\frac{1+x}{1+y}\right)\right],
$$

which, when substituted into 32 , yields

$$
\frac{\left[\frac{\bar{f}(1-u)}{1-k-u z}\right]}{1+i}-\frac{\bar{\delta}}{1+x}=\frac{y}{1+y} .
$$


This can also be written

$$
\left(\frac{\bar{f}(1-u)}{1-k-u z}-\bar{\delta}\right)=y+\alpha_{f}\left(\frac{1-u}{1-k-u z}\right)+\alpha_{\delta},
$$

where

$$
\begin{aligned}
\alpha_{f} & =\bar{f}\left(\frac{i-y}{1+i}\right) \\
\alpha_{\delta} & =\bar{\delta}\left(\frac{y-x}{1+x}\right) .
\end{aligned}
$$

The terms $\alpha_{f}$ and $\alpha_{\delta}$ are the risk premiums associated with the riskiness of $\tilde{f}$ and $\tilde{\delta}$, respectively. At one extreme, where only $f$ is risky, the asset's annual returns are independent. At the other extreme, with only $\delta$ risky, the asset's annual return follows a random walk with a drift of $-\bar{\delta}$.

Once again one can define the effective tax rate as the particular rate that would provide the same incentive to invest as the current system. Because under an income tax at rate $\tau$ the equilibrium condition for holding period yield is

$$
\frac{\bar{f}(1-\tau)}{1+i}-\frac{\bar{\delta}(1-\tau)}{1+x}=\frac{y}{1+y},
$$

equations 36 and 37 can be combined to solve for the effective tax rate analogous to equation 4 in the text:

$$
\begin{aligned}
\tau & =\frac{\left(\bar{f}-\alpha_{f}\right)-\left(y+\bar{\delta}+\alpha_{\delta}\right)}{\left(\bar{f}-\alpha_{\delta}\right)-\left(\bar{\delta}+\alpha_{\delta}\right)} \\
& =\frac{\left(\bar{y}+\delta+\alpha_{\delta}\right)(1-k-u z)-\left(\bar{y}+\delta+\alpha_{\delta}\right)(1-u)}{\left(y+\bar{\delta}+\alpha_{\delta}\right)(1-k-u z)-\left(\bar{\delta}+\alpha_{\delta}\right)(1-u)} .
\end{aligned}
$$

The effective tax rate is precisely the rate that would apply in the absence of risk for a risk-free rate, $y$, and an economic depreciation rate, $\bar{\delta}+\alpha_{\delta}$. Hence two corrections must be made for the effective tax rates calculated above: replace the return, $r$, with a risk-free return and, as suggested by Bulow and Summers, consider economic depreciation to be at rate $\bar{\delta}$ $+\alpha_{\delta} \cdot{ }^{54}$

54. Bulow and Summers, "The Taxation of Risky Assets." 


\section{Comments and Discussion}

Henry J. Aaron: Alan Auerbach has written an ambitious, original, and provocative paper on an important subject. More accurately, he has written several mini-papers on a variety of subjects and grouped them under a single title. My comments are selective.

My first comment concerns the estimates of the capital wastage from tax-related distortions.

To begin at the beginning, the corporation income tax potentially causes a variety of distortions. First, it creates a tax wedge between corporate and noncorporate activity unless other tax provisions offset it. This is the problem on which Harberger wrote his classic article. ${ }^{1}$ This distortion is reflected in a distortion of both the composition of output and the methods of production. Although Harberger did not analyze them, additional distortions would result in the supply of factors of production. Second, the effective tax rate varies among categories of capital goods because taxable depreciation differs from true depreciation by varying amounts across classes of capital goods. The effective tax rate varies across firms both because they employ different mixes of capital goods that are variously taxed and because they have different profit histories and prospects. Although Auerbach late in his paper estimates how variations in profit histories and prospects change effective rates, he does not use these estimates in calculating capital wastage.

These features of the corporation income tax distort factor supplies and cause a misallocation of capital and labor both between the corporate and noncorporate sectors and between various industries and firms within the corporate sector. Some of both kinds of misallocation is

1. Arnold C. Harberger, "The Incidence of the Corporation Income Tax," Journal of Political Economy, vol. 70 (June 1982), pp. 215-40. 
attributable to distortions in output arising from price effects to which consumers respond; some is attributable to shifts in factor intensities as firms respond to factor prices distorted by one or another aspect of the corporation income tax. Harberger included both of these distortions in his analysis of the effects of the corporation income tax on corporate and noncorporate sectors, but his analysis was highly aggregated.

Auerbach omits some of these distortions in his analysis-those arising from shifts in factor supplies because of changes in the remuneration of labor and capital, and in output because the corporation income tax causes shifts in relative product prices. In Harberger's terms, Auerbach omits the output effects of differences in the rate of tax across classes of capital goods. Because of this treatment, some of the distortions that would show up as changes in factor supplies or in the composition of output (if factor supplies and the composition of output were not assumed frozen) show up in Auerbach's model as distortions in factor inputs. If factor supplies could change, some shifts in the intertemporal pattern of consumption and in labor supply would occur. If composition of final output could change, production would tend to shift toward those commodities relatively intensive in tax-favored types of capital, thus driving up prices of types of capital used relatively intensively in expanding sectors-and at least some of these types of capital would be those that were tax-favored. As a result, demand effects would transmute some of the factor-use distortions into factor-supply and output distortions.

The remaining distortions arise for two reasons. Even if all output were produced by one firm, the tax advantages to one class of capital relative to another would cause a firm to alter its mix of capital inputs. Removal of those price distortions would permit the firm either to produce the same output with fewer inputs or to increase output. But Auerbach treats forty-four industries, rather than two, and thirty-four types of capital, rather than one. Because the technology of production differs among firms, tax provisions favorable to certain kinds of capital will cause a reallocation of capital and of labor, and output will be reduced. Rather than calculate the loss of output, one can start with the tax-distorted situation and enquire how much less capital would suffice to produce the observed output if the distortions were removed. This is the question that Auerbach answers.

The answer depends, among other things, on the size of the tax 
distortions and on the substitutability of factors for one another in production. On the size of the tax-distortions, Auerbach's answer is "very large, indeed." His table 4 shows enormous differences in effective tax rates by asset class. These differences translate into a 37.66 percent lower $\rho$ for general industrial equipment than for industrial buildings. Auerbach assumes a Cobb-Douglas production function because it is mathematically tractable, not because it is descriptively realistic.

If one treats the entire corporate sector as a single firm with two types of capital subject to this degree of distortion in the required rate of return, one can calculate either the resulting loss of output or, equivalently, the amount of capital wastage that such a rate-of-return wedge would produce. Assume a production function, $X=L^{a} E^{b} S^{c}$, where $L$ is labor, $E$ is equipment, $S$ is structures, and $X$ is output, standardized so that no scalar is necessary in the production function. We know that roughly 80 percent of net value added accrues to labor and that the value of the quantity of net corporate equipment approximately equals that of net corporate structures. Given these quantities, the implied production function coefficients are $a=0.8, b=0.0768$, and $c=0.1232$. Based on this production function and the rate-of-return advantage of equipment that Auerbach reports in table 4, profit maximizing firms would equalize the money value of equipment and structures in their net capital stocks. The rate-of-return distortion would reduce output by 0.54 percent, or, equivalently, it would imply capital wastage of 2.68 percent.

My second comment concerns the assumption of unitary elasticity of substitution. It is worth noting that, as Auerbach applies it, the adoption of a Cobb-Douglas production function is not equivalent to imposing a unitary elasticity of substitution among all types of capital. Because each industry uses only a few kinds of capital and the production function for each industry is defined only over those types of capital, Auerbach's Cobb-Douglas is equivalent to assuming a unitary elasticity of substitution among included capital goods and labor and a zero elasticity of substitution between each excluded type of capital and each included type of capital and labor. A poll of those assembled here would probably elicit a modal estimate of the average elasticity of substitution of capital for labor of about 0.75 . We would agree that it is likely to vary across industries. Had Auerbach been able to use this value, his estimates of capital wastage would probably have been smaller than they are. But that leaves the question of what the elasticities of substitution among 
types of capital really are. We would again agree that they would vary among classes of capital and among industries, but I am not sure whether our opinions would place a weighted mean value nearer to 1.0 , the assumed value for included capital goods, or to zero, the assumed value for comparisons involving excluded capital goods. The latter value would produce no change in the mix of capital inputs and no "within" distortion (see his table 6). I have no idea how a graph relating "within" distortion to the elasticity of substitution among types of capital would look, except at the end points. Nor do I know what the trade-off would be between "within" and "between" distortion.

In short, I am riding for all it is worth the discussant's famous dodge, the plea for sensitivity analysis. Some effort in this direction is essential because these estimates of distortion are important, and one needs to know how much confidence to place in them. To repeat, we need to know the consequences of different average levels of the elasticity of substitution among types of capital and of dispersion around that average. Even if we cannot estimate these elasticities, at least we can have some sense of how much our ignorance matters.

My third comment relates to policy implications of the empirical section of the paper. The section on the effects of incomplete loss carrybacks and delayed tax savings from losses that are carried forward (table 8) very nicely distinguishes the importance of this adjustment under three tax laws and at three rates of inflation. But there is no indication in the text accompanying table 6 or in table 6 itself of what changes in the corporation income tax, apart from total repeal, will go farthest toward lowering distortion. I strongly suspect, for example, that the idea advanced by two Harvard professors (one of whom, I think, has since left) for first-year capital recovery might go a long way toward reducing the wastage of capital. I fear, however, that that proposal may run afoul of Auerbach's analysis showing the unfortunate consequences of incomplete loss offsets, as first-year capital recovery, at least for a while, would drastically increase losses and possibly their dispersion as well.

Whether Auerbach's estimates of capital wastage are large or small, like beauty, is in the eye of the beholder. They certainly seem insufficient to explain the handwringing by both liberal and conservative economists over the distorting character of present rules for taxing capital income. The answer, I think, is that Auerbach in this article drops only one shoe. 
The other is the personal income tax whose provisions for taxing capital income, together with institutional rigidities, cause additional distortions in the allocation of capital.

Robert E. Hall: Alan Auerbach has presented an interesting and imaginative account of a number of aspects of business taxation, covering some old ground and quite a bit of new ground. I would quibble a little with his title. The paper is really about the taxation of the earnings of corporate plant and equipment. There isn't anything about the interesting topic of taxation of other types of corporate earnings, and there is quite a bit about the taxation of plant and equipment earnings under the personal as well as the corporate income tax.

The paper shows very effectively what a monster the tax system has become, especially in the area of plant and equipment earnings. The system taxes the earnings of structures to subsidize equipment. Under the assumption Auerbach favors, the rate of subsidy on equipment is about 20 percent; the rate of tax on structures, about 30 percent (table 11). The full monstrosity of the system is not yet evident because the tax rate on existing capital is well above the rate on new capital. As time passes, the replacement of capital will erode the tax base. In later years, existing tax rates on structures will not be enough to pay the subsidy on equipment and generate current levels of revenue. All revenue estimates agree that the net revenue from the corporate tax will dwindle in the coming years.

The taxation of plant and equipment is like the old crude oil equalization tax. Under that tax, domestic production was taxed to subsidize imports. Now structures are taxed to subsidize equipment.

The deadweight burden of the unequal taxation of equipment and structures is not small. Auerbach calculates that the same output could have been produced with 2 or 3 percent less capital if the distortion favoring equipment were eliminated from the tax system. The forgone GNP is close to $\$ 10$ billion a year.

The paper also puts a lot of effort into understanding the taxation of corporate income under the personal income tax. There are some very tricky issues in this area. At first, it would appear that the taxation of interest and dividends at rates of close to 50 percent under the personal tax would add quite a bit to the total effective tax rate on corporate income. However, Auerbach argues, as he has in other papers, that the 
taxation of dividends under the personal income tax makes no difference for effective rates on corporate income. When investment is financed by forgoing dividends now, the reduced current tax on dividends exactly makes up for the future tax on dividends financed by the return from the investment. The only personal taxes that matter are the accrual equivalent of the capital gains tax and the tax on interest income. On the margin, Auerbach argues, investment is financed mostly by equity through retained earnings, in which case the personal tax is just the capital gains rate of about 5 percent. Only about one-quarter of finance is through debt, and in that case the personal tax on the interest paid is between 20 and 40 percent.

This view brings up the murky issue of why firms pay dividends. The same firm contemplating cutting dividends to finance investment might just as well think about cutting dividends to retire debt or buy its own shares. Both unambiguously raise the value of the firm. The firm that was free to cut its dividend would easily find a reason to cut the dividend to zero.

A view with very different implications is that firms are precommitted to a certain growth path of dividends. Firms then decide between putting retained earnings into plant and equipment or into bonds. On the margin, all investment is financed by lower holdings of bonds or by issuing bonds.

Table 11 shows how sensitive Auerbach's findings are to assumptions about debt financing versus equity financing and about the tax rate on interest. If inflation is 4 percent, the subsidy rate on equipment is 46 percent if half of investment is debt financed and the rate of personal taxation of interest is 20 percent. On the other hand, if only a quarter of investment is debt financed and the tax rate on interest is 40 percent, the rate of subsidy is only about 7 percent. The tax rates on structures are 16 and 38 percent in the two cases.

My guess is that the effective fraction of debt finance is even above 50 percent because firms think of dividends as largely precommitted. I would also guess that effective taxation of interest income is not much above 20 percent. Opportunities abound for channeling interest to recipients in low tax brackets. Further, large amounts of interest income are simply unreported. The recent uproar over a modest withholding tax on interest suggests that many people think it is their moral right to escape taxation on interest.

Under my assumptions about the personal tax, equipment is heavily 
subsidized and structures are lightly taxed, but the qualitative conclusions of Auerbach's paper are not really changed-there is a major distortion because the tax system favors equipment over structures.

In today's tax system the federal government is pouring billions of dollars into subsidies of business equipment. Like all business subsidies, this one needs to be eliminated forthwith. Policymakers have been led to these heavy subsidies by a combination of trying to tax income and by having separate corporate and personal taxes. The fact that both taxes generate positive revenue conceals their pernicious subsidy of business equipment.

The most promising way to eliminate the gross inefficiencies of business taxation is to junk the current tax system and start again. A progressive consumption tax, administered as a value-added tax, seems the best avenue. It would guarantee effective tax rates of exactly zero on all types of investment, in place of subsidies and taxes as at present. All the efficiency and equity objectives of taxation can be achieved in a straightforward, administratively simple, and practical tax system. In that system, businesses and workers together would pay a tax based on the sales of consumption goods. Workers would receive the benefit of a graduated personal exemption, which could give the system any desired degree of progressivity.

\section{General Discussion}

Joseph Pechman questioned whether the differential tax rate on equipment and structures is the major factor responsible for the observed change in the allocation of capital. He noted significant tax differentials opened up only after 1972 whereas the ratio of investment in equipment to structures began a secular upward movement long before that. Pechman was not convinced that the tax system could fully account for this secular trend. Furthermore he was not aware of other evidence that there has been overinvestment in equipment.

Charles Schultze agreed with Pechman, arguing that the misallocative effects of the tax subsidies may be less for capital stocks than for other economic activities. If demand for investment goods is relatively inelastic to change in user costs, as suggested by the accelerator investment model, then the main effect of the subsidies is to increase firms' profits rather than the capital stock. 
Jeffrey Shafer cautioned that there may be more equipment around than meets the eye: investment that is intrinsically related to structures may be fairly easily disembodied for tax purposes. While installation of central air conditioning is considered an expenditure on structures for tax purposes, installation of individual air conditioners that can be disconnected is considered equipment expenditure. A durable surface floor is an investment in structures, whereas carpets on the floor are an investment in equipment. William Brainard observed that there is considerable latitude in the classification of expenditures and that some of the reported changes may simply reflect more aggressive accounting practices by firms in response to tax incentives.

Several discussants argued that the discussion of the "misallocation" of the capital stock should recognize that social objectives other than technical efficiency are involved. George Perry suggested that the differential tax treatment reflected a desire to maximize investment stimulus per dollar of revenue lost. Congress, with the objective of increasing the capital stock and productivity, assumed that equipment was more responsive to tax subsidies than structures. Michael Lovell recalled Robert Crandall's argument that many members of Congress may favor equipment investment over structures investment because they want to encourage employment in the older industrial centers in the Northeast and Midwest by subsidizing plant modernization while avoiding the subsidization of plant movement to the Sun Belt.

John Shoven commented that the focus on the misallocation of capital within the corporate sector drew attention away from other distortions caused by the corporate income tax. Compared with the misallocations Auerbach focused on, Shoven's own work indicated that greater welfare losses from corporate income taxation came from the intertemporal misallocation of resources and from the misallocation of resources between the corporate and noncorporate sectors. 